\title{
WestVirginiaUniversity
}

THE RESEARCH REPOSITORY @ WVU

Volume 118 | Issue 1

Article 13

September 2015

\section{Inventing Patents: A Story of Legal and Technical Transfer}

L. R. Bradford

American University in Cairo

Follow this and additional works at: https://researchrepository.wvu.edu/wvlr

Part of the Intellectual Property Law Commons

\section{Recommended Citation}

L. R. Bradford, Inventing Patents: A Story of Legal and Technical Transfer, 118 W. Va. L. Rev. (2015).

Available at: https://researchrepository.wvu.edu/wvlr/vol118/iss1/13

This Article is brought to you for free and open access by the WVU College of Law at The Research Repository @ WVU. It has been accepted for inclusion in West Virginia Law Review by an authorized editor of The Research Repository @ WVU. For more information, please contact ian.harmon@mail.wvu.edu. 


\title{
INVENTING PATENTS: A STORY OF LEGAL AND TECHNICAL TRANSFER
}

\author{
L. R. Bradford*
}

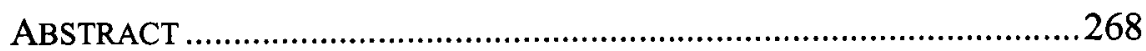

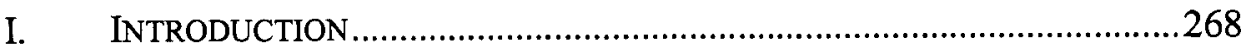

II. A BRIEF HISTORY OF EARLY PATENT LAW ........................................ 277

A. The Significance of Early Patent Law for Development in

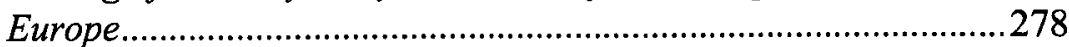

B. The Historical Roots of the Venetian Patent System .....................280

1. Craft Guilds as a Foundation for Formal Patent Structures .....283

2. Privileges for New Hydraulic Devices as a Foundation for Formal Patent Rules ............................................................284

3. The Implications of Perceiving the Venetian Act as a

Response to European Technical Achievement

III. THE WORLD TRADING SYSTEM OF THE 13TH CENTURY ........................290

IV. THE TEChNOLOGY COVERED By EARLY PROTO-PATENTS-

GLASSMAKING AND HYDRAULIC MILLING TECHNOLOGY -WERE

ALL IMPORTS FROM EASTERN SOCIETIES ..............................................297

A. The Glassmaking Techniques Protected by Guild Rules

Originated in Byzantium and the Islamic Empire..........................298

B. Early Municipal Proto-Patents Covered Irrigation, Dredging and Milling Technology that Likely Diffused to Europe from

Andalusian Spain and the Levant ..................................................307

V. LEGAL PRECURSORS TO THE 1474 ACT: THE USE OF INDUSTRIAL MONOPOLIES IN BYZANTIUM AND THE LEVANT .....................................315

A. Tax Farming: A Long-Known Monopoly......................................316

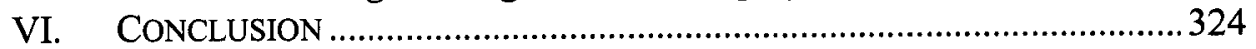

* Intellectual Property Counsel \& Research Fellow in Law, American University in Cairo. I would like to thank Robert Brauneis, David D. Kirkpatrick, John Duffy, Amina Elbendary, David Schleicher, Ted Sichelman, Adam Talib, Zorina Khan, Lisa Anderson, Karim Abdel Latif, and the participants of the Middle East Colloquium at AUC for generous insights and helpful comments on earlier versions of this Article. Any remaining errors are my own. 


\section{ABSTRACT}

Critics and proponents alike assume that patent law is an institutional innovation of Europe and the United States. This Article argues that the form developed, at least in its earliest incarnations, as a cross-cultural hybrid, born of contest and conversation between medieval East and West. Early patent-like laws responded to the migration of skilled artisans from the medieval Middle East to a still-developing Western Europe, and may also have represented a migration of legal form as well. The development of patent law thus can serve as a case study of knowledge and legal transfer between divergent societies. The story of patent law's development in 15th century Venice showcases how local adaptation of institutional forms contributes to the process of legal innovation, and foreshadows how the law will continue to develop as it migrates across the globe today.

\section{INTRODUCTION}

This is a story about the creation of a new legal institution. The Venetian Act of March 19, 1474, the first formal patent law on record, is considered a "true legal innovation." The law granted to inventors the right to exclude others from using their inventions for a limited period, much like today's patent law. ${ }^{2}$ This creation of a property interest in new technology allowed decentralized market coordination of innovative activities in the early modern era. The patent form thus represents a break from historical practice, wherein sovereigns encouraged pet artistic and scientific projects through direct patronage. ${ }^{3}$

From Venice the invention patent form spread quickly to the rest of Europe. Unlike tort, contract, or property law, whose roots stretch back thousands of years, formal patent law is considered a creation of Western Europe. ${ }^{4}$ Patents for invention developed alongside a corpus of medieval European legal institutions that promoted private investment in production. ${ }^{5}$ An

1 22 (2007).

John F. Duffy, Inventing Invention: A Case Study of Legal Innovation, 86 TEX. L. REv. 1,

2 The Venetian Statute was first described in a 1936 article by Giulio Mandich. Giulio Mandich, Privative Industriali Veneziane (1450-1550), 34 RIVISTA DI DIRITTO COMMERCIALE 511 (1936), translated in Giulio Mandich, Venetian Patents (1450-1550), 30 J. PAT. OfF. Soc'y 166, 176-80, 201-02 (1948).

3 See, e.g., F. D. Prager, The Early Growth and Influence of Intellectual Property, 34 J. PAT. OFF. SoC'Y 106, 111 (1952) (describing ancient prizes and monopolies awarded by sovereigns for achievement in arts, crafts and sciences).

$4 \quad$ See Duffy, supra note 1, at 19.

5 For an overview of these institutions, see, for example, NATHAN ROSENBERg \& L.E. BirDzell, JR., HOW THE WEST GREW RICH: THE ECONOMIC TRANSFORMATION OF THE INDUSTRIAL WORLD 22-23, 113-36 (1986). 
influential school of historians credit these institutions for the "Great Divergence": the unprecedented growth and technological achievement of Europe and the United States relative to the rest of the world in the modern age. $^{7}$ Nonetheless, patent law's distinctive form and abrupt appearance in 15 thcentury Venice have yet to be satisfactorily explained. ${ }^{8}$

This Article offers an unexpected answer. It argues that early patentlike laws facilitated the transfer of technical expertise gradually from the medieval global East to the still-developing West. Patents for invention may have represented a transfer of legal form, as well. Venice, in 1474, sat at the hub of a lucrative trading empire that stretched across the Eastern Mediterranean. The city maintained close commercial relationships with many of the most powerful city-states of the time, including Cairo, Damascus, and Constantinople. I argue that formal patent law arose gradually in Venice because of increasing trade with and migration from these relatively more developed Eastern territories. ${ }^{9}$

6 For a detailed analysis of this phenomenon, see generally, KENNETH POMERANZ, THE Great Divergence: China, Europe, and the Making of the MOdern World ECONOMY (2000).

7 See, e.g., H. l. DutTon, The Patent System And InVentive Activity During the IndUSTRIAL ReVOLUTION, 1750-1852 (1984); B. Zorina Khan \& Kenneth L. Sokoloff, Historical Perspectives on Patent Systems in Economic Development, in THE Development Agenda: Global Intellectual Property and Developing Countries 215, 218, 239-41 (Neil Weinstock Netanel ed., 2009); Douglass C. NorTH, Structure aND Change IN ECONOMIC History 17, 164-66 (1981); Douglass C. NoRTh \& Robert Paul Thomas, The Rise of the WESTERN WORLD 17-18 (1973) [hereinafter NORTH \& THOMAS I]; ROSENBERG \& BIRDZELL, supra note 5, at 22-23, 33; Joel Mokyr, Intellectual Property Rights, the Industrial Revolution, and the Beginnings of Modern Economic Growth, 99 AM. ECON. REv. 349, 349-55 (2009) (acknowledging inefficiencies in the incentives offered through the patent system but concluding that the possibility of large payoffs encouraged inventors and benefitted society); Douglass C. North \& Robert Paul Thomas, An Economic Theory of the Growth of the Western World, 23 ECON. HisT. REv. 1, 16 (1970) [hereinafter North \& Thomas II].

8 Previous legal scholarship on the Venetian Statute has focused exclusively on political and social currents within Italy or Europe. See Duffy, supra note 1, at 21-23; Christopher May, The Venetian Moment: New Technologies, Legal Innovation and the Institutional Origins of Intellectual Property, 20 Prometheus 159 (2002); Craig Allen Nard \& Andrew P. Morriss, Constitutionalizing Patents: From Venice to Philadelphia, 2 REv. L. \& ECON. 223 (2006); Prager, supra note 3, at 130-33; Ted Sichelman \& Sean O'Connor, Patents as Promoters of Competition: The Guild Origins of Patent Law in the Venetian Republic, 49 SAN DIEGO L. REV. 1267 (2012); see also NORTH \& THOMAS I, supra note 7, at 8 (arguing that the predominant factor which induced the institutional innovations of modern Europe was internal population growth).

9 Cf. E. Wyndham Hulme, The History of the Patent System Under the Prerogative and at Common Law, 12 L.Q. REV. 141, 141-42 (1896) (noting without elaboration that the slow infiltration of improved processes from the East was primarily responsible for Europe's progress in the manufacturing arts in the early modern age); Prager supra note 3, at 118-19 (asserting that the first link in the chain of documents leading to patent laws relates to migrations of artisans, some of whom came west from Byzantium, but declining to explore the connection further). 
Understanding how patent law developed in Venice provides insight into how legal institutions evolve. This process occurs not just within jurisdictions, but also as a result of transfers between them. Yet the factors that allow transfers to take root and become assimilated locally are not wellunderstood.

The Venetian example offers a case study of legal migration between different political and economic systems. In Venice's case, competition between new European city-states for skilled migrants led Venice and other cities to offer rewards to those who brought new knowledge to the community. ${ }^{10}$ These immigrants, in turn, brought expectations of state patronage and monopoly privileges from Eastern cities to the evolving merchant republics of Italy. ${ }^{11}$ In deference to influential guild interests, early patent awards were limited only to those who could teach the community novel and significant new arts. ${ }^{12}$ Thus emerged the distinctive Venetian patent structure. Negotiations between merchant elites, local craft guilds and skilled newcomers produced the distinctive patent form inaugurated in Venice.

This historical claim is novel. Previous legal scholarship has credited social and technological currents within Europe for the appearance of formal patent privileges. ${ }^{13}$ Even as a growing literature has begun to describe the influence of natural philosophers from the $\mathrm{Arab}^{14}$ East on the scholarly revival of the Italian Renaissance, historians have paid less attention to craft and technical advances. ${ }^{15}$ Scholars in specialty fields such as medieval engineering or renaissance glassmaking have separately noted the importance of Eastern influence for Western development in the medieval period. ${ }^{16}$ This Article is the first to combine these historical strands to make a larger argument about the origins of European legal rewards for invention.

This Article also offers an example of the new avenues of crosscultural legal inquiry that have become possible due to the digitization of

10 See infra text accompanying notes 265-272.

11 Cf. Maximilian Frumkin, Early History of Patents for Invention, 26 TrANSACTIONS NEWCOMEN SOC'y 47, 47 (1947) (hypothesizing that patents originated in the "Eastern Empire" because it was a "paradise of monopoly, privilege and protection").

12 See Sichelman \& O'Connor, supra note 8, at 1269.

13 See sources cited supra note 8.

14 I am following a convention of using the term "Arab" or "Islamic" to refer to scientific advances achieved in the Arab-run Middle East during the Middle Ages. It should be noted that many significant scholars and merchants of the period were not Muslim or Arab, but were part of Jewish, Persian, or Christian communities and merely lived under Islamic and Arab rule. See, e.g., Jim Al-Khalili, The House of Wisdom: How Arabic Science Saved Ancient KNOWLEDGE AND GAVE US THE RENAISSANCE xiii-xxi (2011).

15 For a good overview, see id; Michael Hamilton MORGaN, Lost History: THE ENDURING LEGACY OF MUSLIM SCIENTISTS, THINKERS, AND ARTISTS (2007).

16 See infra text accompanying notes 193-204, 223-226, 293-308. 
previously remote historical archives. While patent historians have in the past occasionally acknowledged a possible connection between Venetian rewards for invention and the city's extensive Eastern trade, most have treated the prospect as inscrutable. ${ }^{17}$ Until recently, these connections were prohibitively difficult to trace. ${ }^{18}$ This Article takes advantage for the first time of the largescale digitization in the last decade of many collections of European, Jewish, and Middle-eastern historical archives. ${ }^{19}$ It also draws on Arabic and Hebrew source material, which has not previously been examined for relevance to the development of early European legal institutions such as patent law. This examination, which has by no means exhausted the topic or the archives, reveals the new research projects possible in what have become known as the "digital humanities.",20

The claim that non-European technology and practice had a role in inspiring the Venetian Patent Statute is significant for three reasons. First, it is important because it disrupts the debate over the global extension of patent systems. Where both proponents and opponents have assumed patent protections to be a Western innovation imposed on the developing world, the history suggests that the form itself was a kind of cross-cultural hybrid, born of contest and conversation between East and West. ${ }^{21}$ Some economic and legal historians cite patents as evidence of homegrown Western cultural or

17 See, e.g., Frumkin, supra note 11, at 47 ("It is likely that the modern monopoly originated in Byzantium, and became the invention patent at the Renaissance when numbers of inventions appeared."); Giulio Mandich, Primi Riconoscimenti Veneziani di un Diritto di Privativa Agli Inventori [Early Venetian Recognition of the Exclusive Rights of Inventors], 7 RIVISTA DI DIRITTO INDUSTRIALE 101 (1958) (unpublished translation on file with the author) (hypothesizing that the first supplicant to ask for a monopoly right to a new invention was "perhaps conforming to a common practice in the Greek-Byzantine era"); Prager, supra note 3, at 117 ("For the industrial arts, the Middle Ages were the Dark Ages indeed. Once more, as in remote antiquity, inspiration had to be derived from the Orient."). However, drawing on mostly European historical sources, they have gestured at the prospect, but left it unexamined. See, e.g., Frumkin, supra note 11 , at 47 .

$18 \quad C f$. POMERANZ, supra note 6, at 27 (discussing how new technologies have made comparative historical research projects more feasible than in the past).

19 For some open access examples of significant medieval manuscripts, see Cairo Genizah, CAMBRIDGE DIGITAL LIBR., http://cudl.lib.cam.ac.uk/collections/genizah (last visited Oct. 8, 2015); Middle East Document Ctr., Mamluk Studies Resources, UnIV. OF ChI., http://mamluk.uchicago.edu/ (last visited Oct. 8, 2015); Read Classic eBooks, OPEN LIBR., https://openlibrary.org/read (last visited Oct. 8, 2015).

20 See, e.g., Univ. of Oxford, People \& Projects, Digital HumaN., http://digital.humanities.ox.ac.uk/people-projects (last visited Oct. 8, 2015).

21 Another example of this influence is the muqãrada contract, which was widespread in Arab caravan trading and influenced the form of the commenda contract and its use in longdistance shipping in medieval Italy. See ABRAHAM L. UdOVITCH, PARTNERSHIP AND PROFIT IN MEDIEVAL ISLAM 172-74 (1970). 
institutional superiority. ${ }^{22}$ Development scholars continue to assail the patent system as a purely Western instrument of imperialism or neocolonialism. ${ }^{23} \mathrm{In}$ fact, the form arose out of more multifaceted amalgamation of Eastern and Western practice than has previously been appreciated. ${ }^{24}$

Greater appreciation of this shared history may interrupt some of this received wisdom in the patent law and development debate. An understanding of patent law as a continuation of an older, shared institutional history can make such laws more palatable to development scholars. A longer view of the gradual development of patent law can illustrate to patent's proponents the benefits of allowing further innovation as patent law migrates back East.

Second, the story of patent law's development in Venice contributes to a growing literature on the nature of legal transfers. ${ }^{25}$ Because of the perceived

22 See, e.g., ROSENBERG \& BIRDZELL, supra note 5, at 22-33, 136-39 (arguing that uniquely Western institutions that decentralized decision-making about innovation and technical change, such as early patent grants, underlay the rise of the West relative to the rest of the world); North \& Thomas II, supra note 7, at 15-16 (positing that increased private profitability of innovation through patent grants led to a restructuring of institutions that enabled Western Europe to rise above economic challenges that hobbled other societies); see also JOEL MOKYR, THE LEVER OF RICHES 231 (1990) (noting the uniquely European culture of scientific exploration).

23 See, e.g., George Sombe MuKaka, Reap What You Have Not SoWn: Indigenous Knowledge Systems AND InTEllectual Property Laws IN SOUTH Africa 52 (2010); Andreas Rahmatian, Neo-Colonial Aspects of Global Intellectual Property Protection, 12 J. WORLD INTELL. PROP. 40 (2009); Vandana Shiva, North-South Conflicts in Intellectual Property Rights, 12 PEACE REV. 501, 502 (2000) (asserting that modern patents represent efforts to "recolonize" the developing world); Constantine Vaitsos, Patents Revisited: Their Function in Developing Countries, 9 J. DEV. STUd. 71, 77, 83 (1972).

24 See, e.g., Toby E. Huff, The Rise of Early Modern Science: Islam, China ANd the WEST (2d ed. 2003) (attributing the failure of modern technology to develop in Islamic or Chinese lands to differences and deficiencies in their legal systems and institutions); James $M$. Murray, Entrepreneurs and Entrepreneurship in Medieval Europe, in THE INVENTION OF ENTERPRISE 88, 93-100 (David S. Landes, Joel Mokyr \& William J. Baumol eds., 2010) (attributing the "commercial revolution" of Europe from the 13th century onward mostly to interactions between urban centers of Southern and Northern Europe and innovative business practices initiated in each territory); Toby E. Huff, What the West Doesn't Owe Islam, 22 ACAD. QUESTIONS 504 (2009) (arguing that Western Christian legal and institutional traditions developed separately and apart from Islamic influence).

25 John Gillespie defines a "legal transfer" as
the horizontal (state to state) and vertical (international organization to state) movement of laws and institutional structures. Such transfers can be imposed or voluntary, encompass entire legal systems or single legal principles, and integrate similar or different cultures. Within recipient countries, legal transfers may permeate state and non-state social institutions; or, in the case of many developing countries, such transfers may be formulated as state law superimposed on indigenous legal structures. Legal transfers are increasingly linked to international legal harmonization projects sponsored by large trading nations, international donor agencies, and transnational corporations.

John Gillespie, Towards a Discursive Analysis of Legal Transfers into Developing East Asia, 40 N.Y.U. J. INT'L L. \& POL. 657, 662 (1998). 
success of Western legal institutions, part of the law and development project of recent decades has included urging developing economies to adopt institutional structures, such as formal patent regimes, that replicate the standards and procedures common in the West. ${ }^{26}$ An assumption underlying this project is that legal regimes and institutions can be transplanted cleanly into new environments and will work in a similar manner. ${ }^{27}$ This is known as a "conduit" theory of legal transfer. ${ }^{28}$

In contrast, a growing body of research demonstrates that legal transfers often take root in unintended ways in receiving countries. Recipients interpret global legal scripts according to norms, epistemological assumptions, and power frameworks that differ from those advanced by the donors. ${ }^{29}$ For example, historical work on the development of patent systems, even within Europe, indicates that patent legal regimes tend to reflect the underlying social divisions and cultural priorities of their host country. ${ }^{30}$ The divergence from a positivist notion of fixed law only increases as frameworks like patent law migrate to non-Western legal and cultural contexts. ${ }^{31}$ Law and development scholars, therefore, argue for a "social construction" model of legal transfers that analyzes the interpretation of the law by recipient stakeholder communities. $^{32}$ This more discursive approach takes account of the multiple pathways through which the local meaning of a law may be constructed. ${ }^{33}$

Patent law is one of the paradigmatic legal "scripts" in the process of being transferred. ${ }^{34}$ Multinational enterprises in the pharmaceutical, software,

26 For a general overview and critique of these projects, see John Gillespie \& Pip Nicholson, Taking the Interpretation of Legal Transfers Seriously: The Challenge for Law and Development, in LAW AND DEVElopment AND THE Global Discourses of LEGAL TRANSFERS 1, 1-26 (John Gillespie \& Pip Nicholson eds., 2012).

27 See John Gillespie, Relocating Global Legal Scripts in Local Networks of Meaning, in LAW AND DEVElopment AND THE Global Discourses of Legal TRANSFERS, supra note 26, at 29 [hereinafter Gillespie, Relocating].

$28 \quad I d$. at 30.

29 Gillespie \& Nicholson, supra note 26 , at 6.

$30 \quad$ Gillespie, Relocating, supra note 27, at 29; Khan \& Sokoloff, supra note 7, at 217, 231.

31 See, e.g., Christopher Arup, The Transfer of Pharmaceutical Patent Laws, in LAW AND DEVElopment AND THE Global Discourses of Legal TRANSFERS, supra note 26, at 121-41. See generally Amy Kapczynski, Harmonization and Its Discontents: $A$ Case Study of TRIPs Implementation in India's Pharmaceutical Sector, 97 CAL. L. REV. 1571 (2009).

32 Gillespie \& Nicholson, supra note 26, at 9-10, 15; see also Gillespie, supra note 25, at 657 (defining "discourse analysis" of legal transfers as framing the transfer as a series of regulatory conversations between stakeholders).

33 Gillespie, supra note 25, at 714, 718; see also Susan K. Sell, The Quest for Global Governance in Intellectual Property and Public Health: Structural, Discursive, and Institutional Dimensions, 77 TEMP. L. REV. 363 (2004).

34 See, e.g., Jerome H. Reichman \& Rochelle Cooper Dreyfuss, Harmonization Without Consensus: Critical Reflections on Drafting a Substantive Patent Law Treaty, 57 DukE L.J. 85, 
and electronic fields have pushed for enforcement of patent claims across the globe as they enter new geographical markets. ${ }^{35}$ Since the signing of the multilateral Trade-Related Agreement for the protection of Intellectual Property Rights (TRIPs) in 1994, at least 49 developing countries have enacted or revised patent laws to bring them into compliance with United States and European Union legal norms. ${ }^{36}$ While the effectiveness and desirability of these new regimes for their host countries is a hotly contested topic, little research has explored the mechanics of how these new laws take shape and become rooted, if at all, in different legal and social contexts. ${ }^{37}$

The history of Venice's patent law provides a pre-colonial case study of how laws designed to foster technical knowledge transfer across cultural and legal boundaries and become rooted in new institutional contexts. In this case, the use of monopolies was common throughout the ancient world and persisted in the Near East and Asia into the medieval period. ${ }^{38}$ These monopolies were rarely designed to foster or reward innovation, however. In the medieval Near East, industrial monopolies enhanced state economic power over vast land empires and, when delegated to private management, also eased the burdens of tax collection. ${ }^{39}$

In the post-Roman West, however, the use of industrial monopolies had been all but completely eradicated for the millennium preceding the Venetian Statute. ${ }^{40}$ As Eastern technical knowledge flowed West during the late medieval period, commercial monopolies reappeared. ${ }^{41}$ Some of these monopolies were intended to ease the collection of taxes, as in the East. Guild

87-90 (2007) (describing the push by patent holders to "harmonize" patent laws globally under the GATT TRIPs framework). A "legal script" refers to the rules, norms, and standards described in written legal documents, as well as the ideals, doctrines, and tacit assumptions that give meaning to written rules and regulations. See Gillespie, Relocating, supra note 27, at 29.

35 Reichman \& Dreyfuss, supra note 34 , at 87.

36 See, e.g., Sisule F. Musungu \& Cecilia Oh, The Use of Flexibilities in TRIPs by Developing Countries: Can They Promote Access to Medicines?, CoMmISSION ON INTELL. Prop. RTS., InNOvation \& Pub. Health (2005), http://www.who.int/intellectualproperty/studies/ TRIPSFLEXI.pdf?ua $=1$.

37 For two notable exceptions, see Arup, supra note 31; Kapczynski, supra note 31.

38 E.g., Linda T. Darling, Revenue-Raising and Legitimacy: Tax Collection and FINANCE ADMINISTRATION IN THE OTTOMAN EMPIRE, 1560-1660, at 120-28 (1996) (discussing the history of tax farming and commercial monopoly practices); Michael Hudson, Entrepreneurs. From the Near Eastern Take Off to the Roman Collapse, in THE INVENTION OF ENTERPRISE, supra note 24, at 8,12-17 (describing public leasing of enterprises, workshops and lands to private managers).

39 See infra text accompanying notes 337-344.

40 See Prager, supra note 3, at 122. Exclusive common law claims to mining tracts or recovered agricultural land were still occasionally awarded, however. ERICH KAUFER, THE ECONOMICS OF THE PATENT SYSTEM 2-4 (1989) (describing privileges for mining claims); Murray, supra note 24, at 91 (describing privileges for reclaimed agricultural land).

41 See Prager, supra note 3, at 118-20. 
statutes, which granted exclusive authority over industrial sectors in return for tax revenue, are an example of this type of monopoly. ${ }^{42}$ Others served new purposes. As wealth in the Italian trading cities such as Venice depended on trade revenue rather than tax receipts from agriculture, cities competed to attract skilled newcomers. This competition produced a second, novel type of monopoly for those who could establish new trades or industries. ${ }^{43}$

This history holds lessons for the modern patent harmonization project. Just as in Venice, we should expect that as patent law migrates to today's developing world, it will adapt to and reflect the underlying power structures of each host economy. This kind of legal adaptation and growth is arguably more important for development than the transfer of technical knowledge. Local adaptations of patent law may form the basis of productive legal innovations with far-reaching effects, as occurred in Venice.

Finally, this history contributes to the normative debate over the nature and purpose of patent laws. The dominant consensus today is that patents exist to promote novel, conceptual creativity. ${ }^{44}$ The Venetian Statute is the recognized foundation for these invention monopolies. ${ }^{45}$ Because the nonWestern origin of the earliest Venetian crafts has been invisible, historians have misconstrued early Venetian proto-patent laws as responding, at least partially, to original invention in the region rather than to slower and less dramatic

42 See Thomas B. Nachbar, Monopoly, Mercantilism, and the Politics of Regulation, 91 VA. L. REV. 1313, 1320 (2005) (noting that an early innovation in the medieval administration of the English monarchy was to "shift the responsibility for domestic revenue collection from royal officers to select town residents ... [which] became the merchant guilds").

43 Cf. Nard \& Morriss, supra note 8, at 249 (noting that "[b]ureaucratizing patents increased the value of the cittadini's [merchant elite's] positions within the Venetian state by giving them a new set of benefits to bestow").

44 See, e.g., American Inventors Protection Act of 1999 (AIPA), Pub. L. No. 106-113, 113 Stat. 1501 (1999) (codified as amended at 35 U.S.C. $\S 102$ (2012)) (revising the novelty requirement under United States law to preclude protection for any invention available to the public anywhere in the world before the filing date); Duffy, supra note 1, at 9 ("[T] he hard work society is attempting to encourage in the patent system is conceptual in nature.").

45 See Bruce W. Bugbee, Genesis of American Patent and Copyright Law 23-24 (1967) (crediting the Venetian Republic with "the world's first known patent system ...."); DONALD S. Chisum ET AL., PRINCIPLES OF PATENT LAW 11 (3d ed. 2004) (noting that the Venetian Republic enacted "the first known patent statute"); Duffy, supra note 1, at 21 ("The policy of granting monopolies specifically and solely to encourage technological development first crystallized in the Venetian Republic."); M. Frumkin, The Origins of Patents, 27 J. PAT. OFF. SoC'Y 143, 143 (1945) ("After 1450 the grant of real patents became quite systematic in Venice." (emphasis added)); Prager, supra note 3, at 107-08 (noting that the system of patent monopolies for inventions "was perfected in Italy, mainly in Venice, during the fifteenth century"); Frank D. Prager, Standards of Patentable Invention from 1474 to 1952, $20 \mathrm{U}$. CHI. L. REV. 69, 71 (1952) (stating that the requirement of inventive merit for patentability began with the Venetian Statute); Edward C. Walterscheid, The Early Evolution of the United States Patent Law: Antecedents (Part 1), 76 J. PAT. \& TRADEMARK OfF. SoC'Y 697, 706 (1994) (noting "patents of monopoly, originated first in Italy, primarily in Venice, during the early part of the fifteenth century"). 
processes of adaptation. ${ }^{46}$ While historians acknowledge that patent rewards were at times used to import long-existing crafts, these later laws are largely viewed as deviations from the example set in Venice. ${ }^{47}$

This emphasis on conceptual innovation has obscured the importance of teaching in early patent law. Historically, patents were used less as a reward for absolutely novel inventions than implied promises to teach useful arts known elsewhere to the less skilled. ${ }^{48}$ The investment that medieval patents sought to foster was in the training of workers in a new industry or technique. ${ }^{49}$ The modern patent bargain-monopoly in return for disclosure ${ }^{50}$-assumes that the newly disclosed knowledge will diffuse easily across firms, borders, and communities to enrich human societies. ${ }^{51}$ This view neglects the historical role that patents played in encouraging the teaching of a known craft in a new community, and so transferring tacit knowledge across boundaries. ${ }^{52}$ In this way, the medieval patent system fostered a balance between entrepreneurs, who developed new techniques, and laborers, who wanted to learn them. In a world without autonomous commercial firms, patent law enabled investments in

See, e.g., Luca Molà, Inventors, Patents and the Market for Innovations in Renaissance Italy, in 32 HISTORY OF TECHNOLOGY 7 (Ian Inkster ed., 2014) (stating that Venetian patent law provided the juridical and economic mechanisms that enabled inventions originating in North and Central Europe to diffuse over the continent); see also infra text accompanying notes 114-134.

47 See, e.g., BUGBEE, supra note 45, at 14 (noting that in England "'letters patent' . . were issued for all sorts of privileges and grants" and that "true patents of invention-which were late in appearing - comprised only a very small fraction of the total"); Duffy, supra note 1, at 25-33 ("In sum, the history from the sixteenth through to the mid-nineteenth centuries shows English law gradually forgetting or losing any concept of invention inherited from Venetian law.").

48 See Carlo Marco Belfanti, Guilds, Patents, and the Circulation of Technical Knowledge: Northern Italy During the Early Modern Age, 45 TECH. \& CulTuRE 569, 578 (2004) (arguing that patents worked in tandem with the secrecy of the guilds, in that the former were issued to introduce arts or devices unknown to the local guilds with the expectation that the art or device would then be assimilated into the local guilds); E. Wyndham Hulme, On the Consideration of the Patent Grant, Past and Present, 13 L.Q. REv. 313, 314 (1897) (arguing that "instruction of the public" in a new industry was the essential consideration of Britain's early patent system); see also Sichelman \& O'Connor, supra note 8, at 1278 (noting that early Venetian patents implicitly contained a teaching requirement).

49 See Belfanti, supra note 48 , at 570-71.

so See 35 U.S.C. $§ 112$ (a) (2012) (requiring a detailed written specification for patentability); THOMAS GREEN FESSENDEN, AN ESSAY ON THE LAW OF PATENTS FOR NEW INVENTIONS 49 (1st ed. 1810) ("The specification is the price which the patentee is to pay for his monopoly.").

51 For critiques of this proposition, see, for example, John F. Duffy, Reviving the Paper Patent Doctrine, 98 CORNELl L. REV. 1359, 1389-92 (2013); see also Hulme, supra note 48, at 318 (critiquing the evolution of written disclosure as the consideration for a patent grant); Nathan Rosenberg, Economic Development and the Transfer of Technology: Some Historical Perspectives, 11 TECH. \& CULTURE 550, 555, 566 n.34, 570-71 (1970) (noting various reasons why impersonal technology transfer often fails).

52 Hulme, supra note 48, at 313-15; see also Mario Biagioli, Patent Republic: Representing Inventions, Constructing Rights and Authors, 73 Soc. RES. 1129, 1138 (2006). 
training. Greater acknowledgement of this historical emphasis on teaching and dissemination can inform current debates over proper patentable subject matter, the problem of non-practicing entities, and the use and efficacy of the current patent regime as a tool to transfer practical knowledge to developing economies.

This Article is organized as follows. Part II describes the current understanding of patent law and its appearance in early modern Venice, which scholars typically attribute to trends internal to medieval Europe, such as the rise of medieval guilds and new hydraulic engineering techniques. Part III widens the perspective to explain how Venice's development in the late middle ages occurred within a larger context of newly interconnected trading systems in the Middle East and Asia. Part IV shows how the two foundational influences on patent law's development in Venice, glassmaking and watermilling, depended directly on technology and know-how imported from Byzantium and the Eastern Mediterranean via the migration of skilled artisans.

Part V examines the potential historical influences on the legal form of the patent monopoly. In particular, this section argues that tax farming-that is, delegation of oversight and taxing authority over a segment of the economy in return for payment-played an important role in fostering knowledge transfers and investment in new trades in the medieval Eastern Mediterranean. Finally, Part VI concludes with an exploration of the implications of understanding patent law as the result of legal transfers between vastly different political and economic systems.

\section{A BRIEF HISTORY OF EARLY PATENT LAW}

The first modern, generally-applicable patent law appeared in Venice in the 15 th century. This law worked alongside other important institutional innovations to channel capital into productive private ventures. These legal innovations fueled the explosive growth of wealth and technological achievement of the early modern West. However, the reasons for the emergence of a fully formed statutory patent law in medieval Venice are not well-understood. ${ }^{53}$ Laws granting privileges and monopolies for industrial devices emerged slowly in the Middle Ages as an exception to the hostility toward monopolistic industrial rewards in classical times. Patent historians have credited two trends with the law's development in Venice: the rise of organized craft guilds, such as Venice's famous glassmakers, and the use of new hydraulic methods and machinery in the city's public works. As we shall see, both of these trends owe much to transfers of expertise from across the Mediterranean, although that connection has been underappreciated in mainstream patent scholarship.

\footnotetext{
53 See Nard \& Morriss, supra note 8, at 236 (calling the appearance of statutory patent law in Venice in 1474 a "puzzle to be solved").
} 


\section{A. The Significance of Early Patent Law for Development in Europe}

In 1474 the Venetian Senate passed the first known statutory patent law on record. It reads as follows:

WE HAVE among us men of great genius, apt to invent and discover ingenious devices; and in view of the grandeur and virtueof the City, more such men come to us every day from diversparts. Now, if provision were made for the works and devices discovered by such persons, so that others who may see them could not build them and take the inventor's honor away, more men would then apply their genius, would discover, and wouldbuild devices of great utility and benefit to our commonwealth.

Therefore:

BE IT ENACTED that, by the authority of this Council, every person who shall build any new and ingenious device in this City, not previously made in our Commonwealth, shall give notice of it to the office of our General Welfare Board when it has been reduced to perfection so that it can be used and operated. $^{54}$

This statute has many features that continue to define modern patent law. ${ }^{55}$ The Act requires inter alia, disclosure of a new, "ingenious" and useful invention to the State in return for right to exclude others from making or practicing the same invention. The subject matter to be patented is not limited to sectors or industries, but includes any device that in the opinion of the Senate offers a benefit to the Commonwealth. ${ }^{56}$ The Act requires novelty, but in a territorial sense only: "any new and ingenious device... not previously made in our Commonwealth." The reference to an "ingenious device" seems to require inventive merit, so that the invention must not be a trifling, all too obvious application of known technology. ${ }^{57}$

In short order, Venetian patent practice inspired similar laws throughout Europe. From Venice, the idea spread to other capitals in Europe so that by the end of the 16th century all of the Western European states had instituted similar forms safeguarding the rights of "inventors," all inspired by the Venetian law of $1474 .^{58}$ The lasting influence of the Venetian statute on the

\footnotetext{
$54 \quad$ Mandich, supra note 2, at 176-77.

$55 \quad$ Nard \& Morriss, supra note 8, at 234.

56 Mandich, supra note 2, at 177.

57 Id; see also Duffy, supra note 1, at 22 (arguing that Venetian patent law contained an implicit kind of non-obviousness, or inventive step requirement).

58 Carlo Marco Belfanti, Between Mercantilism and Market: Privileges for Invention in Early Modern Europe, 2 J. INSTITUTIONAL ECON. 319, 327 (2006); Prager, supra note 3, at 108.
} 
shape of modern patent law has prompted one historian to proclaim that "the international patent experience of nearly 500 years has merely brought amendments or improvements upon the solid core established in Renaissance Venice." $" 59$

Economic historians, led by Nobel laureate and Professor Douglass North, credit medieval patent law as one of the key factors that drove the unprecedented growth of scientific knowledge, technology and ultimately, wealth in modern Western Europe. ${ }^{60}$ North was a pioneer in the field of institutional economics, which holds that efficient economic institutions, and particularly secure property rights, are the key to economic growth. ${ }^{61}$ Property rights provide incentives to invest, to trade, and to finance. North argued that patent laws similarly provided incentives to invest in research and development and other innovative efforts. ${ }^{62}$

Institutional economics offers several complementary theories about the ways in which this new system increased British and Western European wealth over other areas. Unlike earlier state patronage systems, patents themselves bestowed no rewards. Instead, they worked alongside market mechanisms to direct private rewards to those who provided the most useful technologies. ${ }^{63}$ North emphasized that private patent rights enabled innovators to capture gains that more closely approximated the social gains offered by their inventions. ${ }^{64}$ Professor Nathan Rosenberg and L.E. Birdzell have focused on patents as part of a range of institutional innovations that created autonomous spheres of commercial decision-making shielded from the demands of tradition, culture, state, or religious authority. ${ }^{65}$ The ability to respond directly to market conditions tapped the expertise of artisans and merchants closest to the trade, and so encouraged innovation and experimentation. ${ }^{66}$ More recently, Professors B. Zorina Khan and Kenneth L. Sokoloff have argued that increased transparency, predictability and accessibility of the 18th- and 19th-century patent systems in the United States over that of Britain and France of the same period partially accounts for

59 BUGBeE, supra note 45, at 24; see also CRAIG AllEN NARD, THE LAW OF PATENTS 10 (3d ed. 2013) ("[T]o paraphrase the American philosopher, Alfred North Whitehead, all modern patent regimes consist of a series of footnotes to the Venetian patent statute of 1474.").

60 NORTH, supra note 7, at 17; ROSENBERG \& BIRDZELL, supra note 5, at 20-24.

61 E.g., NORTH, supra note 7; North \& Thomas II, supra note 7, at 1; see also DANI RODRIK, GETTING INSTITUTIONS RIGHT 1 (2004) ("There is now widespread agreement among economists studying economic growth that institutional quality holds the key to prevailing patterns of prosperity around the world.").

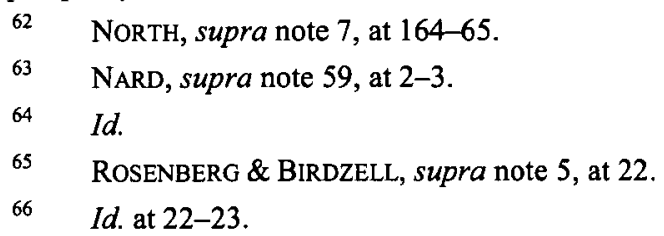


different levels of technical achievement and economic growth between these nations. ${ }^{67}$

The perceived success of the patent systems of Europe and later the United States have animated projects to export similar regimes to today's developing economies. ${ }^{68}$ The lack of formal mechanisms to protect property rights and reward innovation are widely cited as leading causes of technical stagnation and lower per capita wealth in developing regions. ${ }^{69}$ This claim is applied to conditions in contemporary society, and also as an historical explanation for the lack of an industrial revolution in once-leading regions such as China and the Arab Middle East. ${ }^{70}$ The multilateral TRIPs agreement now mandates establishment of patent laws for all participants in the World Trade Organization. ${ }^{71}$ One aim of this harmonization effort, at least nominally, has been to recreate the legal institutions that fostered economic growth and scientific progress in modern Europe and the United States.

\title{
B. The Historical Roots of the Venetian Patent System
}

Despite all of the emphasis on patent institutions as an important feature of development policy, we do not fully understand how such laws initially took root in the medieval West. The emergence of a fully formed

\begin{abstract}
67 Khan \& Sokoloff, supra note 7, at 230-31.
68 Id. at $239-40$ ("[T] effective policies, and proposals to bridge this divide have become a global priority ... . [F]or all of their flaws, the market-orientation of effective patent institutions comprises the most productive means of inducing technological and social progress."); see, e.g., Keith E. Maskus, Intellectual Property Rights and Economic Development, 32 CASE W. RES. J. INT'L L. 471, 472 (2000) (" $[E]$ vidence is emerging that stronger and more certain ... [intellectual property rights] could well increase economic growth and foster beneficial technical change, thereby improving development prospects ...."). This call is not without critics, of course. See, e.g., Joseph E. Stiglitz, Economic Foundations of Intellectual Property Rights, 57 DUKE L.J. 1693, 1696 (2008) (arguing that a "poorly designed intellectual property regime-one that creates excessively "strong" intellectual property rights-can actually impede innovation").

69 See, e.g., Timothy Besley \& Maitreesh Ghatak, Property Rights and Economic Development, in 5 HaNDBOOK OF DevelopmenTAL ECONOMICs 4525, 4583 (Dani Rodrik \& Mark Rosenzweig eds., 2010) ("Effective states in the current context are those that support institutions that allow households and firms to enjoy secure property rights."); NORTH, supra note 7 , at 110 ("Third World countries are poor because the institutional constraints define a set of payoffs to political/economic activity that do not encourage productive activity.").
\end{abstract}

70 See, e.g., HUFF, THE RISE OF EARLY MODERN SCIENCE, supra note 24, at 45-60; ROSENBERG \& BIRDZELL, supra note 5, at 137.

71 See Frequently Asked Questions About TRIPs in the WTO, WORLD TRADE ORG., http://www.wto.org/english/tratop_e/trips_e/tripfq_e.htm\#SingleUndertaking (last visited Oct. 8, 2015). 
statutory patent law in medieval Venice is something of a puzzle. ${ }^{72}$ Precedents have not been located in either Roman law or medieval Canon law, the principle sources of regulatory authority in early medieval Europe.

Patent law emerged as an exception to classical hostility to innovation, generally, and to the notion of state commercial monopolies. No notion of "intellectual property" existed in Greek and Roman antiquity. ${ }^{73}$ During Greek and Roman times, the work of building, fixing, and making things was often done by slaves, and so signified a low status. ${ }^{74}$ Works of craftsmanship were valued, but craftsmanship itself was not. ${ }^{75}$

In antiquity, innovation itself was viewed warily. Human affairs were long considered to be cyclical, and arts and technology were associated with established tradition rather than any process of invention. ${ }^{76}$ Antipathy toward the institution of state monopolies was also widespread. In 483 C.E., Emperor Zeno declared illegal state-created monopolies on "anything . . . in the common use of mankind." "The influence of Zeno's law persisted throughout the legal culture of late antiquity and early medieval Europe. ${ }^{78}$

Even if Roman law had not cast a shadow over the idea, state monopolies for inventions were unlikely to appear in Europe during the chaotic centuries that followed the disintegration of the Roman Empire. The craft guilds that had existed in Hellenistic and Roman cities disappeared with the decline of urban spaces. ${ }^{79}$ Society devolved back to subsistence-level farming. ${ }^{80}$

72 See Nard \& Morriss, supra note 8, at 236 (calling the appearance of statutory patent law in Venice in 1474 a "puzzle to be solved").

73 See KAUFER, supra note 40, at 1 ("In Egypt and other ancient cultures, no patent-like institutions have been discovered, and it is likely that none existed ...."); PAMELA O. LONG, OpenNess, Secrecy, Authorship: Technical ARTS AND the Culture of KNOWLedge from ANTIQUITY TO THE RENAISSANCE 77 (2001) [hereinafter LONG, OPENNESS SECRECY AUTHORSHIP] (noting that evidence of the ancient concept of intellectual property is lacking); Frumkin, supra note 11, at 47 ("At the outset, it must be stated that there were no patents for inventions in the ancient world."). For a discussion of the positive attitudes toward craftsmanship that did exist, see Pamela O. Long, Invention, Authorship, "Intellectual Property," and the Origin of Patents: Notes Toward a Conceptual History, 32 TECH. \& Culture 846, 848-51 (1991) [hereinafter Long, Origin of Patents]; Prager, supra note 3, at 112-13.

74 LONG, OPENNESS SECRECY AUTHORSHIP, supra note 73, at 77-78; Long, Origin of Patents, supra note 73, at 848; Prager, supra note 3, at 113.

75 LONG, OPENNESS SECRECY AUTHORSHIP, supra note 73, at 77-78.

76 See E.H. Gombrich, Eastern Inventions and Western Response, 127 DAEDALUS 193, 19394 (1998).

77 The text of Zeno's Edict is codified in the Code of Justinian at 4.59. CoDE JUST. 4.59 (Zeno 483).

78 Prager, supra note 3, at 115, 122 ("Throughout the Middle Ages, Zeno's law was in effect. It was frequently re-enacted locally.").

79 LONG, OPENNESS SECRECY AUTHORSHIP, supra note 73, at 75. 
The embryonic states that survived lacked the sophistication and the resources to support an incentive policy for innovation. ${ }^{81}$

From the 10th century onward, striking changes took place in the economic and political environment of Western Europe. ${ }^{82}$ A steady increase in population sent people out of the feudal manors to cultivate new land, and to settle in the surviving old Roman cities. ${ }^{83}$ Trade expanded between European regions and across the Mediterranean. ${ }^{84} \mathrm{~A}$ new monetary economy began to replace the feudal system of land for compulsory labor. ${ }^{85}$

Against this backdrop, Frank D. Prager, the leading American scholar of the early patent system, provides two explanations for the emergence of formal patent law in the early Renaissance. ${ }^{86}$ One was the rising importance of medieval craft guilds in the newly prosperous Italian trading cities. ${ }^{87}$ As cities took shape in medieval Europe, skilled artisans banded together to seek recognition for the value of their craft knowledge as a commodity separate from the articles they produced. ${ }^{88}$ Others have built on Prager's work to herald the Venetian glassmakers' guild as the earliest and most influential guild to do so. ${ }^{89}$ The second trend identified by Prager was the use by the new cities of grants of privilege, or "quasi-patents," for those who could perform useful operations connected with hydraulics and water-power. ${ }^{90}$

80 See, e.g., JANET L. ABu-Lughod, Before European Hegemony: The World System A.D. 1250-1350, at 44 (1989) (describing the descent of Europe after the fall of Rome into fragmented territories relying on subsistence farming and feudal serfdom).

${ }_{81}$ See Duffy, supra note 1, at 20 ("In Europe at least, the absence of patents can be explained partly because Europe lacked a state with sufficient sophistication to develop a patent policy ....").

82 NORTH \& THOMAS I, supra note 7 , at 33.

$83 \quad I d$. at $33-38$.

84 Id. at $33,49-50$.

$85 \quad I d$. at $38-40$.

86 See Prager, supra note 3, at 123-28.

87 Id. at 126-28; see also Nard \& Morriss, supra note 8, at 233.

88 LONG, OPENNESS SECRECY AUTHORSHIP, supra note 73, at 88-93; see Prager, supra note 3, at 126-30.

89 See, e.g., LONG, OPENNESS SECRECY AUTHORSHIP, supra note 73, at 89-93; Belfanti, supra note 58, at 322; Long, Origin of Patents, supra note 73, at 870-75; W. Patrick McCray, Creating Networks of Skill: Technology Transfer and the Glass Industry of Venice, 28 J. EUR. ECON. HIST. 301, 316 (1999); Frumkin, supra note 45, at 144; Walterscheid, supra note 45, at 704; Joanna Kostylo, Commentary on: Venetian Statute on Industrial Brevets (1474), PRIMARY SOURCES ON COPYRIGHT (1450-1900), www.copyrighthistory.org/cam/tools/request/showRecord?id=commentary_i_1474 (last visited Oct. 9, 2015).

90 Prager, supra note 3 , at 123-26. 


\section{Craft Guilds as a Foundation for Formal Patent Structures}

Prager and independent historian Pamela Long argue that the regulation of technical knowledge as a public benefit by the guilds laid the conceptual foundation for patent law in Venice. ${ }^{91}$ The glassmakers of Venice were the first and most influential guild on record to regulate craft knowledge as a communal asset. ${ }^{92}$ The Venetian glass guild, as early as 1271 , promulgated limits on the use and dissemination of specialized skills. ${ }^{93}$ The regulations proscribe technical standards for practitioners. ${ }^{94}$ More significantly, they treat glassmaking techniques as proprietary, to be used only for the benefit of the guild and the city. ${ }^{95}$ Practice of the craft or transmission of artisanal knowledge outside of Venice was strictly forbidden. ${ }^{96}$ In successive years, the penalties for disobeying were increased, a sign both of the increasing importance of such craft knowledge and the practical difficulties in enforcing the ban. By the mid$1400 \mathrm{~s}$, the penalty for practicing glassmaking outside of Venice was a heavy fine and imprisonment for a term of three months. ${ }^{97}$ In nearby jurisdictions, the penalty for practicing crafts outside the territory was death. ${ }^{98}$

Recognition of the value of artisanal techniques such as glassmaking led the city to offer rewards and privileges to those who could teach new ones. This occurred gradually in Venice and culminated in the 1474 Statute. Similarly, other European states, eager to establish their own glass industries, offered inducements for artisans to settle in their cities and train their guilds. ${ }^{99}$ As the glass skills of the Venetians migrated north throughout Europe, so did

91 Long, Origin of Patents, supra note 73, at 875 ("One result of the view that craft knowledge constituted a form of intangible property was the development of the patent."); Prager, supra note 3, at 108 ("The idea [of intellectual property] was first accepted by certain guilds. Under their apparent influence it was approved, implicitly and sometimes expressly, by legislators and administrative lawyers."); see also McCray, supra note 89, at 316 ("The skills of Muranese glassmakers represent a form of communal property which ... contributed to the development of early patents, especially in cities such as Venice.").

92 See sources cited supra note 89.

93 Long, Origin of Patents, supra note 73, at 873-75; see also McCray, supra note 89, at 316 ; Prager, supra note 3, at 127-29 (listing later guild regulations of textile workers that began to recognize proprietary rights to craft techniques).

94 Long, Origin of Patents, supra note 73, at 875.

95 LONG, OPENNESS SECRECY AUTHORSHIP, supra note 73, at 90.

96 Id.

97 McCray, supra note 89, at 306.

98 Frumkin, supra note 45, at 144; see also LUCA MOLÀ, THE SILK INDUSTRY OF RENAISSANCE VENICE 43, 45 (2000) (describing bounties for the murder of fugitive textile artisans offered by Genoa, Lucca and Bologna).

$99 \quad$ McCray, supra note 89 , at 324, 333. 
the nascent system of rewarding monopolies to importers of novel techniques and industry. ${ }^{100}$

\section{Privileges for New Hydraulic Devices as a Foundation for Formal} Patent Rules

The other explanation for the development of the 1474 Act, espoused by early patent historians such as Professor Giulio Mandich and Mr. Prager, points to the emergence at this time of new and more intensive use of water power, typically through use of vertical water mills. ${ }^{101}$ By the twelfth century, the state of technology in Europe inexplicably reached a turning point. Individuals surrounded by ancient waterwheels and grain mills gradually realized new applications for waterpower that matured into greater industrial productivity. ${ }^{102}$ City rulers increasingly realized the importance of attracting engineers with advanced technical knowledge to dredge and secure harbors, to build ships and armaments, and to employ new milling and mining techniques. ${ }^{103}$ The competition for sophisticated engineers led cities to offer privileges and rewards for those who could bring advanced hydraulic technology. ${ }^{104}$

Such privileges appeared all over Europe, but the earliest and most well developed records are from late 13 th-century Venice. ${ }^{105}$ The first privileges granted simple permissions to build to those, typically immigrants, who sought to erect new structures or undertake advanced hydraulic work on the city's public waterways. ${ }^{106}$ The Venetian Senate issued letters patent, or "open letters," to individuals signifying permission to operate and in some cases offering tax amnesties, favorable loan terms, or housing as additional inducements to engineers and manufacturers. ${ }^{107}$ Later, in response to requests

$100 \quad$ Id. at 324; Frumkin, supra note 45 , at 144.

101 Mandich, supra note 2, at 182, 186 (noting that most of the initial privilege applications in Venice were for "hydraulic devices").

102 See LynN White, JR., Medieval Technology and Social Change 84 (1962) ("By the eleventh century the whole population of Europe was living so constantly in the presence of one major item of power technology that its implications were beginning to be recognized.").

103 Eliyahu Ashtor, The Factors of Technological Progress in the Middle Ages, in Technology, Industry and TRADE: ThE LeVANT Versus Europe 1250-1500, at 23-24 (B.Z. Kedar ed., 1992) [hereinafter TECHNOLOGY, INDUSTRY AND TRADE]; Belfanti, supra note 58, at $322-23$.

104 Belfanti, supra note 58, at 322-23; Prager, supra note 3, at 125.

105 Prager, supra note 3 , at 125.

106 Mandich, supra note 17, at 7-25; Prager, supra note 3, at 125-26.

107 Mandich, supra note 17, at 7-14. 
by the artisans themselves, the city realized it could save resources by promising a monopoly over exploitation of any new device instead. ${ }^{108}$

These two trends-guild protection of craft knowledge and municipal privileges for new hydraulic devices-converged in 1474 in Venice to produce a statute that promised a ten-year monopoly to anyone who "by their skill and industry" discovered ingenious works and devices. From Venice, the notion of patent privileges for the introduction of new arts and manufactures spread over the continent. For example, a Bolognese glassworker who had trained in Venice received the first industrial privileges granted in France in $1551 .^{109}$ Early "invention" patents were similarly issued to Italian glassworkers in Antwerp, Holland, England, Germany, and Austria. ${ }^{110}$ By the end of the 16th century all of the Western European states had instituted laws safeguarding the rights of "inventors," inspired by the Venetian law of 1474."

It is widely acknowledged among early patent scholars that the purpose of these early patent statutes and privileges was to import foreign inventions. ${ }^{112}$ This fact can hardly be avoided, as this aim is stated in the text of the 1474 Act: the aim is to attract men "from divers parts" to discover arts and devices "not previously made in our Commonwealth." An emphasis on promoting domestic innovation would not occur until much later. ${ }^{113}$

However, most scholars have assumed that the techniques sought were imported from neighboring areas in Italy or wider Europe. ${ }^{14}$ This assumption is understandable based on the inherent bias of the sources available in European archives and languages. The archives of Venice and other medieval

\footnotetext{
$108 \quad$ Id. at 16.

109 Mandich, supra note 2, at 206.

110 LONG, OPENNESS SECRECY AUTHORSHIP, supra note 73, at 93.

111 Belfanti, supra note 58, at 327.
}

112 E.g., Paul A. David, Intellectual Property Institutions and the Panda's Thumb: Patents, Copyrights, and Trade Secrets in Economic Theory and History, in GLOBAL DiMENSIONS OF InTEllectual Property Rights in Science and Technology 19, 44 (Mitchel B. Wallerstein, Mary Ellen Mogee \& Roberta A. Schoen eds., 1991) ("Patents began as instruments used by noble or republican governments in later medieval and early Renaissance Europe primarily to induce the transfer and disclosure of foreign technologies."); Mandich, supra note 2, at 177 ("While reference is made to an invention, novelty is required in a territorial sense only ...."); Nachbar, supra note 42 , at 1324.

113 See Hulme, supra note 48, at 313-19 (arguing that the original benefit sought through the issuance of patents was the promise to work the patented method in the jurisdiction and so train others in its use).

114 See, e.g., E. Ashtor, A Social AND Economic History of the NEAR EAST IN The MiddLE AGES 16-23 (1976) (listing the migrations of artisans and the resulting sharing of new production techniques throughout Western Europe as one of most important causes of technological development in the later middle ages, but recognizing the "Oriental" origin of only the raw materials); Molà, supra note 46, at 17 (stating that Venetian patent law enabled inventions originating in North and Central Europe to diffuse over the continent). 
cities refer only to patentees from other European territories. ${ }^{115}$ Most of Venice's early patent recipients came from Germany or neighboring cities. ${ }^{116}$ The earliest grantees in other jurisdictions were often Venetians. The grants themselves often named arts according to their use in neighboring jurisdictions, such as privileges for weaving "in the Flemish style." vibrant circulation of techniques and devices within the Latin West only.

Historians of technology held a similarly regional theory of early industrial innovation when the Venetian Patent Statute was discovered in 1936. In the mid-20th century, the study of technological history was still in its infancy. Scholars attempting a more "anthropological" approach to historiography had only just begun researching medieval technology and its development. Marc Bloch, a French scholar, published a pioneering article in 1935 entitled, The Advent and Triumph of the Watermill..$^{118}$ Bloch argued that the watermill had been known in Roman times, but its potential for agricultural and industrial uses was only fully realized by medieval Europeans. ${ }^{19}$ Others, such as American historian Lynn White, built on Bloch's work to argue that the widespread use of watermills and industrial milling technology were a hallmark of a uniquely European "exploratory attitude" toward forces of nature that earlier societies had inexplicably lacked. ${ }^{120}$ This consensus also was based

115 Mandich, supra note 2, at 171-75 (reviewing early patent and proto-patent grants in Venice to supplicants from France, Lombardy, Germany, and within Venice); see also ROBERTO

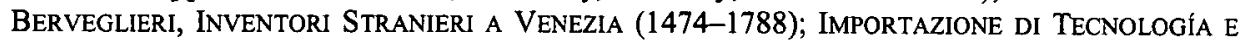
CIRCOLAZIONE DI TECNICI ARTIGIANI INVENTORI: REPERTORIO 22 (1995) (listing the nationality of patent grantees from 1474 onward).

116 Francesca Trivellato, Guilds, Technology, and Economic Change in Early Modern Venice, in Gullds, INNOVATION, AND THE EUROPEAN ECONOMY, 1400-1800, 199, 222 (S.R. Epstein \& Maarten Prak eds., 2008) ("Patents were also instruments to bypass guild monopolies. Barred from Venetian guilds, foreigners-including artisans and entrepreneurs from other Italian states as well as Germans, French, Dutch, and English-often used them with this goal in mind."); Mandich, supra note 2, at 181 ("Among the applicants we find citizens of Venice, subjects of the Republic, foreigners from the Italian peninsula and from the continent; artisans, merchants, noblemen, and for the first time in 1508, a Jew.").

117 See Prager supra note 3, at 122; see also Carlo M. Cipolla, The Diffusion of Innovations in Early Modern Europe, 14 COMP. STUD. IN SOC'Y AND HIST. 46, 46-52 (1972) (describing numerous similar grants through the 18th century in Europe); Hulme, supra note 9, at 142.

118 Marc Bloch, Avènement et Conquêtes du Moulin a eau [The Advent and Triumph of the Watermill] (1935), translated in MARC BLOCH, LAND AND WORK IN MEDIAEVAL EUROPE 136 (J.E. Anderson trans., 1967).

119 Id. at 143-52 (stating that "although the invention of the watermill took place in ancient times, its real expansion did not come about until the Middle Ages" when monasteries and feudal lords needed to conserve manpower for other tasks).

120 MOKYR, supra note 22, at 40; WHITE, supra note 102, at 89. 
primarily on examination of classical and European documentary and artistic sources. $^{121}$

\section{The Implications of Perceiving the Venetian Act as a Response to European Technical Achievement}

This conclusion-that medieval technological development was a European phenomenon-has informed the legal scholarship on the Venetian patent statute. ${ }^{122}$ In 1936, Professor Mandich, an Italian scholar, unearthed the 1474 Statute in the Venetian archives. ${ }^{123}$ Coming a year after Bloch's foundational article on the triumph of the European watermill, it is unsurprising that Mandich's work and the scholars who followed him treat patent law and the medieval technology it covered as a purely intra-European phenomenon.

This notion of a particularly European technical dynamism has shaped the understanding of the Venetian statute as codifying practices that aimed to reward new inventions. ${ }^{124}$ By the 15 th century, when the Venetian Act was codified, Europeans were producing new techniques that arguably qualify as new inventions even under modern standards. ${ }^{125}$ However, the award of privileges and monopolies to merchants who could import foreign artisans of long-standing crafts was still very common throughout Italy. ${ }^{126}$ The Venetian statute memorialized and standardized the irregular practice that had built up over the preceding two centuries of awarding privileges for techniques and

121 See, e.g., BLOCH, supra note 118, at 166-68 (recommending sources for the study of medieval technology that are exclusively Western and Christian, except for one "almost exclusively linguistic" source on Western Asia); Lynn White, Jr., Technology and Invention in the Middle Ages, 15 SPECULUM 141, 156-59 (1940) (recommending sources for the study of medieval technology that are exclusively Western and Christian).

122 See, e.g., Long, Origin of Patents, supra note 73, at 869 n.57 (citing Marc Bloch and Lynn White in a discussion of medieval technology).

123 Mandich, supra note 2, at 166.

124 See, e.g., Long, Origin of Patents, supra note 73, at 869 n.57 (citing Marc Bloch and Lynn White in a discussion of medieval technology); Sichelman \& O'Connor, supra note 8, at 1270 ("While the British system developed from the need to bring in existing arts and artisans from the Continent to train British apprentices, the Venetian system developed in what was then the leading artisanal capital of Renaissance Europe.").

The focus of the English patent system was primarily on the importation of artisanal practices and their related goods that were well-established on the Continent, whereas Venetian patents-at least by the early sixteenth century--were primarily awarded to domestic inventors for truly novel and ingenious arts or machines.

Sichelman \& O'Connor, supra note 8, at 1280.

125 Sichelman \& O'Connor, supra note 8, at 1278.

126 See MolÀ, supra note 98, at 204-14 (describing privileges and inducements offered to agents willing to import "foreign" silk artisans from neighboring territories). 
devices used elsewhere. ${ }^{127}$ While by 1474 the Venetian statute responded to new currents of technological dynamism in Italy and Europe, it did so by building on a technical and legal foundation shaped by the preceding centuries of mostly pure importation from outside of Europe. ${ }^{128}$

So long as Europe is understood to be the sole birthplace of this new technological creativity, these Venetian proto-patent privileges still appear to be patents for "invention." 129 Assumed in many accounts of early Venetian patent law is that even if the inventions it covered did not originate in Venice, they came from somewhere else in Europe. ${ }^{130}$ Thus, the notion of a uniquely European technical renaissance has played a powerful role in sustaining the idea that patent monopolies for the purpose of rewarding essentially novel, conceptual creation arose initially in Venice. ${ }^{131}$

Legal scholars have consequently interpreted the successive centuries of patent law's development as it migrated north throughout Europe as

\footnotetext{
127 Sichelman \& O'Connor, supra note 8, at 1279-80.

128 Cf. Prager, supra note 3, at 119 (asserting that the first link in the chain of documents leading to patent laws relates to migrations of artisans, some of whom came west from Byzantium).
}

129 See, e.g., Sichelman \& O'Connor, supra note 8, at 1277 (describing the initial purpose of Venetian patents as enabling foreigners to bring "innovative new products" to Venice); id. at 1279-80 (noting that Venice's relatively strict novelty requirements ensured that patents were only granted for extraordinary innovation).

130 See, e.g., Trivellato, supra note 116, at 222 (stating that patents were used by foreign artisans and entrepreneurs from other Italian states as well as Germans, French, Dutch, and English to bypass local guild monopolies); Molà, supra note 46, at 17; cf. Cipolla, supra note 117, at 51 (contrasting the diffusion of trades and techniques throughout medieval Europe through the migration of skilled artisans with the failure of such techniques to take root in Turkey because of deficiencies in the "sociocultural beliefs and practices" of that recipient environment). Others, such as Professors Sichelman \& O'Connor, acknowledge the importance of imported techniques to development of patent law, but do not directly explore the origin point of such techniques. Sichelman \& O'Connor, supra note 8, at 1273-74, 1277-80.

131 Legal scholars have consequently interpreted the purposes of early patent law solely in terms of power dynamics between indigenous European stakeholders. See, e.g., Christopher May, The Hypocrisy of Forgetfulness: The Contemporary Significance of Early Innovations in Intellectual Property, 14 REV. INT'L. POL. ECON. 1, 1, 12 (2007) (arguing that the emergence of the patent system was tied to new social divisions of labor that marked Europe's transformation from a feudal to a proto-capitalist economy); Nard \& Morriss, supra note 8, at 249 (arguing that the enactment of a general patent law enhanced the power of the Venetian merchant class because it held exclusive prerogative to hold public offices and award privileges); Sichelman \& O'Connor, supra note 8, at $1273 \mathrm{n} .25,1279$ (explaining the emergence of Venetian patent law as a compromise that protected the monopolistic powers of the guilds while also permitting the entry of foreigners with new and useful knowledge; by foreigners, the authors mean nationals of other European states: Germans, French, Dutch and English as well as other Italian republics). While these accounts describe important dynamics in the founding of patent institutions, they are incomplete. 
departures from patent law's essential purpose. ${ }^{132}$ The follow-on patent grants in France, the Netherlands, Britain, and Germany clearly aimed to import existing industries rather than promote indigenous experimentation. ${ }^{133}$ This remained the primary purpose of patent law up until the Industrial Revolution, and patents for importation were an important part of industrial policy in Britain, France, Italy, Spain, and even, sub-rosa, in the United States until the 19th century. ${ }^{134}$ This long evolution of patent law away from a tool of technological diffusion towards a tool for promoting indigenous experimentation has been obscured by the myths surrounding patent's purpose in Renaissance Venice.

Patent-like awards arose in Venice not to reward domestic or regional innovation but to assimilate craft and technical knowledge that, at least initially, derived from Venice's Eastern trading partners. Venice's main industry during the 13th and 14th centuries was not manufacturing of any kind, but brokering trade between East and West. ${ }^{135}$ The period from $1271-1474$, where we begin to see in Venice the first stirrings of proprietary attitudes toward craft knowledge and the first rules protecting its dissemination, correlate to the period just after Venice had gained a secure foothold into Eastern markets. An examination of both Western and non-Western historical sources strongly suggests that this East-West trade played a foundational role in stimulating the development of patent privileges in Venice.

Europe's relative isolation after the fall of Rome meant that when it rejoined Euro-Asian trading networks, the practices that had developed in the East over the preceding centuries were suddenly available. ${ }^{136}$ Eastern goods and

\footnotetext{
132 See, e.g., BUGBEE, supra note 45, at 14 (noting that in England "“letters patent' ... were issued for all sorts of privileges and grants" and that "true patents of invention-which were late in appearing-comprised only a very small fraction of the total"); Duffy, supra note 1, at 25-33 ("In sum, the history from the sixteenth through to the mid-nineteenth centuries shows English law gradually forgetting or losing any concept of invention inherited from Venetian law.").

133 See Khan \& Sokoloff, supra note 7, at 218-19, 223-24, 235; Sichelman \& O'Connor, supra note 8 , at 1280 .

134 See Khan \& Sokoloff, supra note 7, at 218-19, 223-24, 235; Edward C. Walterscheid, Patents and Manufacturing in the Early Republic, 80 J. PAT. \& TRADEMARK OfF. SOC'Y 855 , 881-84 (1998) (noting that although U.S. law did not provide for patents of importation, in reality, a number of the first patents issued under the first Patent Acts of 1790 and 1793 were patents for arts imported from Britain).
}

135 Ferdinand Braudel, 3 Civilization and CaptTalism $15^{\mathrm{TH}}-18^{\mathrm{TH}}$ Century: The PERSPECTIVE OF THE WORLD 136 (noting that industry did not significantly contribute to Venetian prosperity until the late 16th century); ROGER CROWLEY, CITY OF FORTUNE: HOW VENICE RULED THE SEAS 6-8, 129-30, 272-73 (2011).

136 E.g., ABU-LUGHOD, supra note 80, at 4 (describing the flowering of artisan craft in various centers of the 13th-century Eurasian world system). 
crafts were far superior to anything that existed in the West at this time. ${ }^{137}$ To the Venetians, at the vanguard of commerce with the East, the period appeared miraculous: men came from all over and "every day" brought new discoveries and ingenious devices. ${ }^{138}$ Patent-like legal institutions arose during this period to assimilate this new knowledge. Their form as well was borrowed from older precedents and seems to have leaned on mercantile arrangements in use in the contemporaneous Eastern Mediterranean.

\section{THE World TRADING SYSTEM OF THE 13TH CENTURY}

Patent law originated out of the interstices that connected territorial governments to one another. To understand this, it is necessary to drop back and view how Venice and Western Europe fit into a larger trading system that allowed technical knowledge and legal institutions to migrate across continents and cultures. The purpose of this Part is to outline that larger network.

Venice before the 13th century was at the periphery of a welldeveloped and thriving world trading system. ${ }^{139}$ According to sociologist Janet Abu-Lughod, from about the 8th through the 14th century, Asia and the Middle East were engaged in a systematic network of long-distance trading. ${ }^{140}$ The sequential emergence of first a unified Chinese Empire and then the Arab Conquest of the Middle East brought huge swaths of territory under interconnected and relatively peaceful rule. ${ }^{141}$ Centuries of uninterrupted trade allowed arts, sciences, and technology to flourish. ${ }^{142}$ Europe was mostly

137 Charles Singer, East and West in Retrospect, in 2 HISTORY OF TECHNOLOGY 756, 756 (Charles Singer et al. eds., 1956); see also Stefano Carboni \& David Whitehouse, GLASS of THE SULTANS 3-7 (2001) (Islamic crafts had no rivals by a long shot in Europe).

138 A 1306 sermon by Fra Giordana, a Dominican preacher in Pisa, captures the spirit of the moment. He told his assembled congregation, "Not all the arts have been found; we shall never see an end of finding them. Every day one could discover a new art ... indeed they are being found all the time." Carolyn C. Cooper, Making Inventions Patent, 32 TECH. \& CulturE 837, 837 (1991). The text of 1474 Act repeats this terminology of new arrivals "every day" bringing new arts and sciences. See supra text accompanying note 54.

139 ABU-Lughod, supra note 80 , at 13.
140 Id. at $137-51$.

141 Id. at 3-4, 8, 137-51; see also AL-KHALILI, supra note 14, at 19-24 (describing the emergence of the Islamic Empire); William J. BERNSTEIN, A SPLENDID EXCHANGE: How TRADE SHAPED THE WORLD 75, 78-79 (2008) ("The early Muslim conquests essentially recreated the Pax Romana, but on an even grander scale.").

142 ABU-LUGHOD, supra note 80, at 4; see also David S. Landes, Global Enterprise and Industrial Performance: An Overview, in THE INVENTION OF ENTERPRISE, supra note 24, at 2-3 (claiming that "China was once the richest and proudest of civilizations" and "if there had been Nobel prizes a thousand years ago, they would have gone, just about all, to Muslims"); ARNOLD PACEY, TECHNOLOGY IN WORLD CIVILIZATION 12-38 (1991) (describing the spread of knowledge of dyestuffs, cotton weaving, steel-making, hydraulics, and cultivars through Indian Ocean and Euro-Asian trade of the period). See generally Linda Komaroff, Color, Precious Metal, and Fire: 
isolated from these exchanges and was correspondingly the least-developed area of the three. ${ }^{143}$

Europe's isolation commenced with the fall of the Roman Empire in the 5th century C.E.. A series of invasions and conquests from Germanic tribes fragmented the former Imperial territories and cut them off culturally and administratively from the Eastern former Roman territories. ${ }^{144}$ Western Europe regressed to a largely subsistence agricultural economy. This was the period known in Europe as the "Dark Ages." 145

The Dark Ages were not so gloomy for everyone. The Eastern portion of the Roman Empire remained intact as the Christian kingdom of Byzantium. It ruled over a smaller but strategically important empire from its capital in Constantinople. ${ }^{146}$ On the Arabian Peninsula, a new religion united rival Arab tribes under the banner of Islam. These Arab warriors subdued the Arabian Peninsula and quickly came to control much of North Africa and the Middle East. ${ }^{147}$ In the 600s, Arab armies absorbed parts of Byzantium including Syria and Egypt. ${ }^{148}$ In 644, Islamic forces annexed the territory of Persia. ${ }^{149}$ In the next century, the Islamic caliphates of the Arabs would come to control all of North Africa, Andalusian Spain, and parts of Central Asia and modern Pakistan.

Islamic Ceramics and Glass, in THE ARTS OF FIRE 35, 35-50 (Catherine Hess ed., 2004) (describing the circulation of artistic influences and techniques among Asian and Islamic lands during the medieval period).

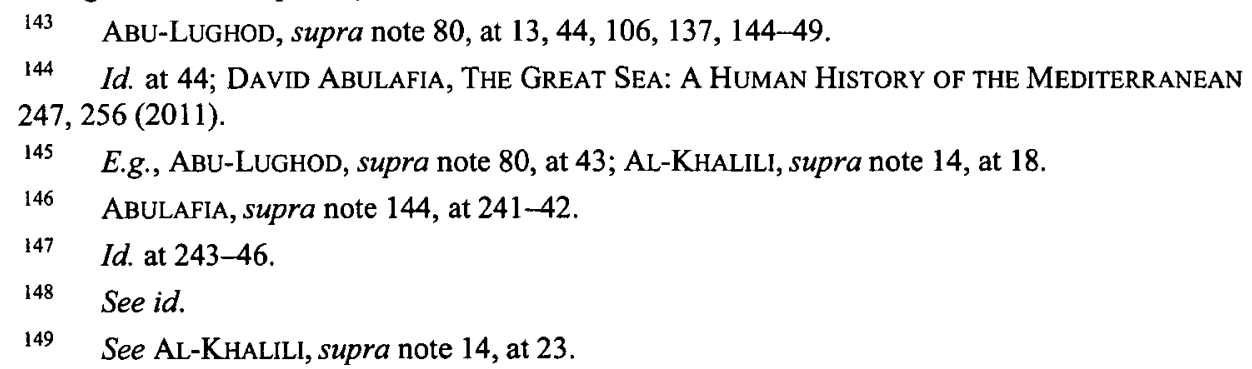


The Arab Conquest unified many parts of the central territories lying between Europe and China. ${ }^{150}$ This period of relative peace and stability allowed the growth of steady long-distance trade networks reaching from India to the Mediterranean. ${ }^{151}$ Arabic, the language of the Koran, became the language of commerce and urban elites in the vast "middle" territory. ${ }^{152}$

\section{Muslim and Byzantine Empires 750 C.E. ${ }^{153}$}

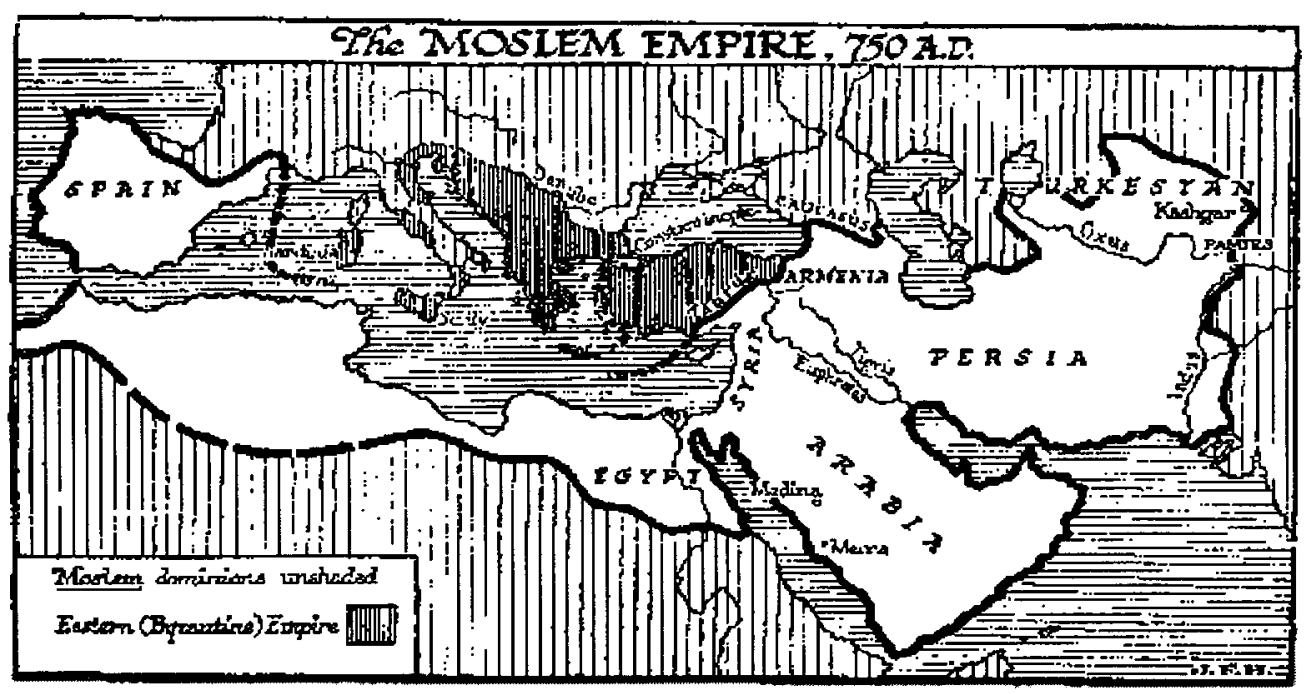

The relative peace and stability of the Arab world in this time allowed for the extension of the Silk Road from Canton to the Mediterranean and beyond. ${ }^{154}$ As the Middle East developed a vast network of safe and reliable caravan routes, sophisticated goods and techniques made their way west from China, India, and Persia into the Levant, North Africa, Islamic Spain, and finally, Western Europe. ${ }^{155}$

150 Timur Kuran, The Scale of Entrepreneurship in Middle Eastern History: Inhibitive Roles of Islamic Institutions, in THE INVENTION OF ENTERPRISE, supra note 24, at 62, 64-65.

151 BERnSTEIN, supra note 141, at 75-79; Catherine Hess, Brilliant Achievements: The Journey of Islamic Glass and Ceramics to Renaissance Italy, in THE ARTS OF FIRE, supra note 142 , at 2 .

152 BERNSTEIN, supra note 141 , at 75.

153 H.G. WELLS, A SHORT HISTORY OF THE WORLD 254 (1922).

154 Id. at 77-81; ABU-LUGHOD, supra note 80, at 198-99.

155 ABU-LUGHOD, supra note 80, at 198-99, 316-40; see also AsHTOR, supra note 114, at 7778; Abu al-Fadl Ja'far ibn 'Ali al-Dimishqi, The Book of Knowledge of the Beauties of 
The rise of the Mongol Empire in the late 13th century brought further stability to trade, at least for a time. By 1280 C.E. the Mongol dynasty of Genghis Khan had unified the northern overland route from the Mediterranean to China under a single system. ${ }^{156}$ For two generations the Mongol Empire maintained the safety and stability of the trans-Central Asian route between the Near and Far East. ${ }^{157}$ The two empires: the Arab and the Mongol, fought over territory, but each maintained profitable routes of trade stretching from the Eastern Mediterranean to modern day China. ${ }^{158}$ Included in these territories was a diverse array of cultures and traditions. While the peace lasted, these societies were free to engage in trade and diplomacy as had rarely, if ever, existed before. $^{159}$

\section{The Mongol Empire Before $1259^{160}$}

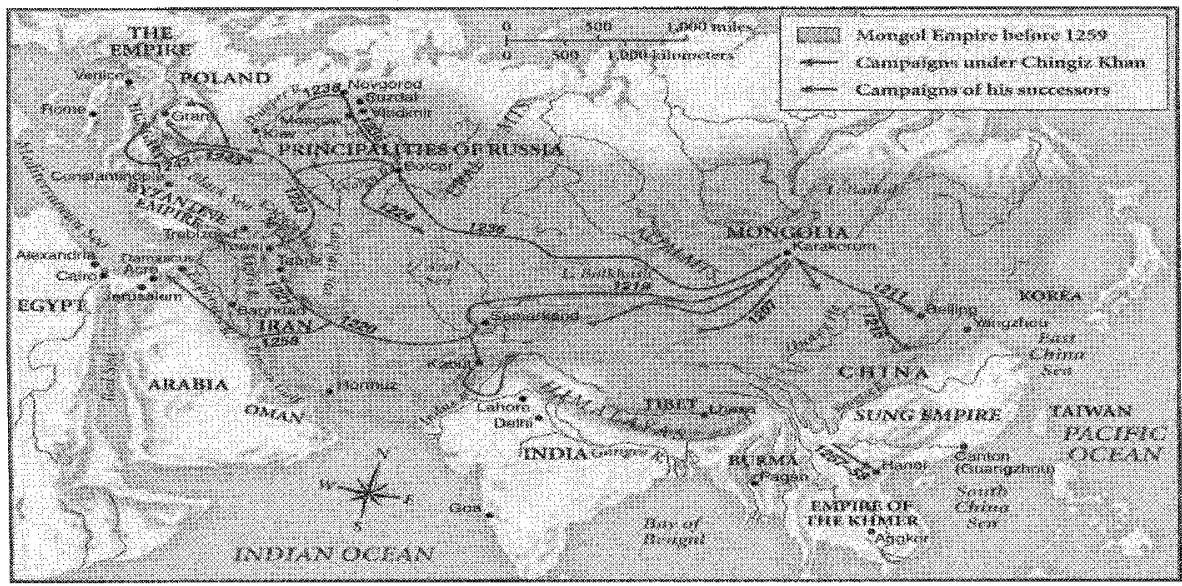

Western Europe lay at the periphery of this global renaissance of trade and scholarship. ${ }^{161}$ The Byzantines controlled access to the Black Sea and the overland routes to Asia. Until the Crusades, the Arabs held the major port cities

Commerce and of Cognizance of Good and Bad Merchandise and of Falsifications, translated and reprinted in Medieval TRADE IN THE MEDITERRANEAN WORLD: ILlustrative DocumentS 27-29 (Robert S. Lopez \& Irving W. Raymond eds. \& trans., 1955) (describing the significant wares from all parts of the world coming through Iraq).

156 ABU-LUGHOD, supra note 80, at 141-44, 157-59, 170-71.

157 Id.

158 E.g., JACK WEATHERFORD, GENGHIS KHAN AND THE MAKING OF THE MODERN WORLD 10506 (2005).

159 Id. at $103-04$.

160 The Mongols, 1200's-1300's, COLUM. UNrv,, http:/www.columbia.edu/itc/mealac/ pritchett/00maplinks/medieval/mongols/mongols.html (last visited Oct. 8, 2015).

161 ABU-LUGHOD, supra note 80, at 13, 105-06, 159-66 (describing Europe's first direct contacts with China via the Mongol Empire in the 13 th century). 
of the Eastern Mediterranean, and therefore controlled trade to India and Southeast Asia through either the Red Sea or the Persian Gulf. Byzantine Greek, Syrian, and other Eastern sailors mostly controlled the Mediterranean shipping routes. ${ }^{162}$ Italy, by virtue of her geography, was the favored port of call for Eastern traders looking to reach European markets. ${ }^{163}$ However, the Italians had little of a sophisticated nature to trade in return. Their wares were mostly local salt, fish, and timber, as well as linen cloth and slaves taken from the European interior. ${ }^{164}$

By 1000 C.E., Venice began to take a more active role in the sea trade. ${ }^{165}$ As Byzantine power waned in the 10th century, Venetian ships took over the patrol of the Adriatic Sea against pirates. ${ }^{166}$ After Venice aided the Byzantines in fending off a Norman invasion in 1082, Emperor Alexius I granted the Venetians special trading rights, including a special Venetian quarter in Constantinople and the right to conduct trade tax free in all Byzantine ports. ${ }^{167}$

Once Venice had free reign in Greek and Adriatic ports, the city's merchants and sailors became a dominant presence in the Mediterranean. ${ }^{168}$ The adoption by Italians of the compass in the 12th century increased the overall volume of trade by making possible winter as well as summer trading runs. ${ }^{169}$ Despite their historical allegiance with Constantinople, Venetian rulers sought commercial relationships with the Muslim rulers of Egypt and Syria and the Berber capitals of North Africa. ${ }^{170}$

162 Frederic C. LANE, Venice: A MARITIME Republic 5 (1973) (stating that before 1000 C.E. "[s]ome Venetians were seamen expert enough to cross the Mediterranean, but Greeks, Syrians, and other easterners carried most of the trade between Venice and the Levant"); see also ABULAFIA, supra note 144, at 248-49 (describing Muslim harassment and piracy aimed at Christian ships, and the dominance of Jewish trading networks between the eastern and western Mediterranean).

163 ABULAFIA, supra note 144, at 248-49; ABU-LUGHOD, supra note 80, at 102-04; MEDIEVAL TrADE, supra note 155, at 33; THOMAS F. MADDEN, VENICE: A NEw HistoRY 48 (2012).

164 ABU-LUGHOD, supra note 80, at 104-05.

165 See generally ABULAFIA, supra note 144, at 278.

166 See ABULAFIA, supra note 144, at 278; MADDEN, supra note 163, at 48, 59.

167 CROWLEY, supra note 135, at 16-17; MADDEN, supra note 163, at 64 .

168 CROWLEY, supra note 135 , at 17.

169 ABU-LUGHOD, supra note 80, at 112.

170 See ABULAFIA, supra note 144, at 298; David Jacoby, Byzantine Trade with Egypt from the Mid-tenth Century to the Fourth Crusade, in THESAURISMATA 30 (2000) reprinted in

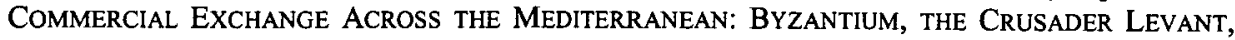
EGYPT AND ITALY 25-77 (2005) [hereinafter COMMERCIAL EXCHANGE] (describing Venice's trading activity in Alexandria and across the Eastern Mediterranean in the 10th through 12th centuries); MADDEN, supra note 163, at 118-19 (describing Venice's efforts to gain a Papal dispensation to trade "nonstrategic goods" with Muslim Egypt). 
The success of the First Crusade widened Venice's trading networks. When the ports of the Eastern Mediterranean ("the Levant") fell to the forces of the First Crusade in 1098, Venetian galleys included the friendly European Crusader States in their regular trading routes. ${ }^{171}$ The merchant cities of Italy fought over privileged access to Crusader ports in Acre and Tyre, in the heart of what had once been the Byzantine and then the Arab empires.

More than any other city or state in Europe then, Venice began to benefit from the relative peace and prosperity of the Arab and Asian states. The major trading routes from Asia ended either in Constantinople, Syria, or Egypt. ${ }^{173}$ By the 12 th century, Venice had uniquely favorable trading rights in the ports of these territories. ${ }^{174}$ By the 14th century, the city had become the dominant gateway for Eastern wares, artisans, and skills into Europe. ${ }^{175}$

Formal patent privileges arose in the 14th and 15th centuries in Venice just after Venice gained a dominant position in the Eurasian trading system. ${ }^{176}$ As Venice increasingly participated in the old trading networks, her people were exposed to several centuries worth of development all at once. Without widespread literacy or established communication methods, this exposure came primarily through the migration of skilled artisans. ${ }^{177}$

Artisan migration came from many sources. The failure of the Crusader enterprise in 1291 sent Venetian citizens home in force, and with them, new techniques and sciences. ${ }^{178}$ The increasing decrepitude of Byzantine

\footnotetext{
171 ABU-LUGHOD, supra note 80, at 108, 123-24.

$172 \quad I d$ at $120-22$.

173 Id. at $137-40$.
}

174 See id. at 110-11. To be sure, Venice's privileges were at times revoked and her rival city, Genoa, also had favorable trading arrangements with the three Eastern Mediterranean gateway territories. Until the 14th century, Genoa alternated with Venice as the dominant Italian sea power. Id. at 120-22. After the fall of the Crusader ports in Syria, Genoa ultimately emerged as the favored trading partner in Constantinople, and Venice strengthened commercial ties with the Mamluk regime in Egypt. Id. at 121, 214-15 (describing Venice's increasing dominance of trade with the Mamluk regime in Egypt). The fall of the Mongol Empire disrupted the overland route East through Constantinople and left Venice decisively the dominant power in the Eastern Mediterranean by the middle of the 14th century. Id. at 128-29.

175 See id. at 102.

176 See, e.g., id. at 46-47 (attributing much of Europe's renaissance in agriculture, mining and manufacturing in the 13 th century to its renewed contact with Eastern trading routes after the Crusades).

177 See S.R. Epstein, Craft Guilds, Apprenticeship, and Technological Change in Preindustrial Europe, 58 J. ECON. HIST. 684, 702 (1998) ("In preindustrial economies, technological crossfertilization occurred overwhelmingly through artisan migration."); Cipolla, supra note 117, at 48 ("Through the ages, the main channel for the diffusion of innovations has been the migration of people.").

178 See Sylvia Auld, Renaissance Venice, Islam and MaHMud the Kurd: A METALWORKING ENIGMA 38 (Leonard Harrow ed., 2004). 
administration led wealthy Greek citizens to emigrate west. ${ }^{179}$ The former colonies of Constantinople looked to Venice as their protector state and commercial hub. ${ }^{180}$

The collapse of many of the great Eastern cities also sent artisans to Venice. The same century during which patent privileges appeared in Venice also saw the conquest of Damascus, Constantinople, Cairo, and the celebrated Islamic kingdom of Al-Andulus in Spain. ${ }^{181}$ These cities had been picked apart by war and taxed to the hilt by opportunistic warrior rulers. ${ }^{182}$ The Black Plague had decimated the workforce and caused the gradual disintegration of trade, irrigation works, and urban industry. ${ }^{183}$ Unrest had caused the migration of thousands. Loss of territory transferred thousands more from Byzantine or Arab dominion to the control of the Italians and principally, the Venetians. ${ }^{184}$ These migrations provided the inspiration for patent law.

Finally, the rising power of the Ottoman Turks provided a further reason to focus on domestic supply of craft objects. Venice had a long and profitable relationship with the Egyptian military Mamluk state. The Mamluks jealously guarded access to the Red Sea spice trade with India, but were content to leave Mediterranean shipping dominance with the Venetians so long as they paid their tolls and taxes. ${ }^{185}$ In the 15 th century, as the Ottomans threatened Egypt, the tolls demanded from the ailing Mamluk sultans grew steeper. ${ }^{186}$ The

\footnotetext{
179 MADDEN, supra note 163 , at 282.

180 See id. at 238-39; see also David Jacoby, Changing Economic Patterns in Latin Romania: The Impact of the West, in THE CRUSADES FROM THE PERSPECTIVE OF THE BYZANTIUM AND THE MUSLIM WORLD (A.E. Laiou \& R.P. Mottahedeh eds., 2001), reprinted in COMMERCIAL EXCHANGE, supra note 170, at part IX, 228-29 (describing how the trade of Latin Romania (the former territories of the Byzantine Empire) became subordinated to the needs of Venice in the late 11 th century).

181 Damascus was conquered by the Mongols in 1401, AULD, supra note 178, at 64; Constantinople fell to the Ottoman Turks in 1453, BERNSTEIN, supra note 141, at 129; the Christian re-conquest of Spain was complete by 1492, ThOMAS F. GLICK, ISLAMIC AND Christian Spain IN The Early Middle Ages 39-40 (Larry J. Simon et al. eds., Brill, 2nd rev. ed. 2005) (1979); and the Mamluk kingdom of Egypt and Syria lost its autonomy to the Ottoman Turks in 1516, AULD, supra note 178, at 64, but had burned the most important Mediterranean port cities centuries before to prevent their capture by the Crusaders. See ABU-LUGHOD, supra note 80, at 146; ASHTOR, supra note 114, at 246. This had left Mediterranean trade largely in the hands of the Italians. See ABU-LUGHOD, supra note 80 , at 122 .

182 See generally ASHTOR, supra note 114, at 242-331 (describing the decline of the economy of Syria, Egypt, and Iraq in the 13th, 14th, and 15th centuries); MAX RoDENBECK, CAIRO: THE CITY VICTORIOUS 100 (1998) (describing the effect of war on Egypt's wealth and trade).

183 ABU-LUGHOD, supra note 80, at 236-39.

184 See infra text accompanying notes 232-248.

185 See, e.g., ABULAFIA, supra note 144, at 293; ABU-LUGHOD, supra note 80, at 239-41.

186 See Benjamin Arbel, The Last Decades of Venice's Trade with the Mamluks: Importations into Egypt and Syria, 8 MAMLUK STUD. REV. 37, 37-38 (2004) (noting practice of late Mamluk sultans to try to extort money from Venetian merchants).
} 
Ottoman Turks took dominion over former Byzantine fiefs in the Eastern Mediterranean and began harassing merchant ships. ${ }^{187}$ The rulers of Venice turned attention to building their own versions of sought-after Eastern crafts such as glass, porcelain, and silk. ${ }^{188}$

The structure of the 13th-century trading system influenced the nascent patent system in Europe. One perennial question for patent scholars is, "Why was Venice first?" 189 Previous scholars have answered that Venice was first to enact formal patent law because of the internal interest group politics of the Venetian elites, ${ }^{190}$ or the need to bargain around the political clout of the Venetian guilds. ${ }^{191}$ To these answers we must add, "because Venice's links to the East were the strongest." The natural migration of so many artisans from Byzantium and the crusader cities created a competition for skilled artisans along Europe's eastern frontiers. As we shall see in Part IV, this competition led cities to offer prizes, rewards, and restrictions related to craft knowledge that would later become the Venetian patent system.

\section{The TeChNOLOgy COVEREd By EARLy Proto-PATENTS-GLASSMAKING AND HYDRAULIC MILLING TECHNOLOGY — WERE ALL IMPORTS FROM EASTERN SOCIETIES}

This Part looks in depth at the two technical trends that underlay Venice's proto-patent privileges and traces their debts to knowledge inflows from the global East. Venice's famed glass industry arose initially out of migration of chemical processes, enameling techniques, and trained artisans from Byzantium and the Crusader states. Similarly, the new emphasis on hydraulic technology in medieval Europe mirrors earlier technical transformations that took place all along the medieval "Silk Road" as divergent areas joined the emerging Eurasian trading system. Venice's proto-patent legal structures arose to regulate the transmission of so much newly-available, valuable industrial expertise.

\footnotetext{
187 See Richard MackenNey, TRAdesmen and Traders: THE WORLd of the Guilds IN VENICE AND EUROPE, C. 1250-C. 1650, at 81 (1987).

188 Id; see also AULD, supra note 178, at 46-47; MADDEN, supra note 163, at 214-15 (discussing the rise of the Ottoman Turks); RHODENBECK, supra note 182, at 101-02 ("From consumers of luxury the Europeans grew to be producers. By the 15 th century the balance of Mediterranean trade had shifted firmly in their favor.").

189 See, e.g., Nard \& Morriss, supra note 8, at 236 (offering answers to this question).

$190 \quad I d$. at $249-50$.

191 Sichelman \& O'Connor, supra note 8, at 1277-78 (explaining the emergence of Venetian patent law as a compromise that protected the monopolistic powers of the guilds while also permitting the entry of foreigners with new and useful knowledge).
} 


\section{A. The Glassmaking Techniques Protected by Guild Rules Originated in} Byzantium and the Islamic Empire

The glassmaking techniques treated as proprietary by the Venetian guilds were initially imported from Byzantium and the territories of the Islamic Empire. By the 15 th century, Venetian glassmakers would pioneer major innovations in glass production ${ }^{192}$ In 1271 , however, Venice's proprietary rules concerning glass techniques represented not craft innovation but a desire to keep a trade advantage over nearby cities. Competition with other gateway cities such as Florence, Bologna, Genoa, and Lucca for the skills of migrating artisans formed the impetus for the first proto-patent laws.

Glassmaking has occurred in Italy since at least Roman times. ${ }^{193}$ The technique of blowing glass to form vessels of different shapes was invented in Mesopotamia (Syria) in the 1st century B.C.E. while under Roman rule. ${ }^{194}$ The Roman conquest of the entire Mediterranean basin and the subsequent Pax Romana allowed for the rapid spread of the new glass-blowing technology. ${ }^{195}$ After the fall of Rome, glass making using glass blowing continued in Italy and other former Roman territories of Western Europe though the resulting articles were generally cruder and less well made. ${ }^{196}$

The kind of glass that made Venice famous in the medieval period was of a new and different type, however. In post-Roman times, a change occurred in tempo, shapes, and materials in all the glass-making centers of the East in connection with the Arab Conquest in the 7th and 8th centuries. ${ }^{197}$ In Egypt, Syria, and Mesopotamia, trailed, ribboned, and pointed forms appeared featuring painted or pincered decoration. In the 9th and later centuries, craftsmen in several Near Eastern countries began experimenting with fine cutting on colorless crystal glass. ${ }^{198}$ These new models incorporated earlier Roman/Byzantine glass blowing and metallic painting techniques into new forms inspired by the Koran and the appreciation for Chinese porcelain designs within the Abbasid Empire. ${ }^{199}$

\footnotetext{
192 E.g., McCray, supra note 89, at 305 (describing the invention of cristallo glass in Venice in the 1450s).

193 D.B. Harden, Glass and Glazes, in 2 A History of TeChNOLOGY: THE MEditerRANEAN Civilizations AND THE MidDle AGEs 322 (C. Singer et al. eds., 1956); Hess, supra note 151, at 3.

194 Harden, supra note 193, at 322; Hess, supra note 151, at 3.

195 Harden, supra note 193, at 322.

196 Id. at 326.

197 Id. at 327.

198 Id.
}

199 See AsHTOR, supra note 114, at 243-44; Hess, supra note 151, at 17 (shapes of Venetian glass inspired by Islamic models); Komaroff, supra note 142, at 38-43. See generally Harden, supra 193, at 342. 
The use of luster painting in the 9th century gave way in the 12th century to the use of enamel and gilding on colored and colorless glass. ${ }^{200}$ Historical evidence is ambiguous about whether enameled glass emerged first in the Christian kingdom of Byzantium or the Islamic centers of Egypt and Syria. ${ }^{201}$ It seems clear, however, that the two traditions influenced each other and developed to some extent in parallel. ${ }^{202}$

Examples of Eastern crafts reached Venice through several means. Byzantium was its own active center of glass production. ${ }^{203}$ Venice's close alliance with Constantinople provided plentiful access to luxury goods and skilled artisans.

The Byzantine era also corresponds to a period of great flourishing in Islamic culture from the 9 th to the 13 th centuries. ${ }^{204}$ The Byzantine and Islamic worlds were deeply enmeshed. ${ }^{205}$ Despite periodic conflict, the two empires maintained diplomatic ties and exchanged gifts, promoted artistic rivalries, and valued similar kinds of luxury goods. ${ }^{206}$ Textiles, metalwork, glass, and gems all circulated between Constantinople and the Islamic lands of North Africa and the Levant. ${ }^{207}$ Venetian officials and merchants who spent long periods of time in the Venetian quarter of Constantinople came in contact with all of these products.

Islamic glass-making techniques circulated throughout Byzantium as well. Al-Muqaddasi, a 10th-century Palestinian geographer, records in his

200 See Harden, supra note 193, at 327-28. Again, the impetus for this technique may have been a desire to emulate the opaque appearance of Chinese porcelain. Id. at 342 .

201 Compare Harden, supra note 193, at 327-28 (stating that gilded and enameled glass most likely emanated from Syria), with HUFF, supra note 24 , at 78-80 (asserting that the earliest Islamic enameled glass was produced sometime in the late 12th or mid-13th century whereas Byzantine enameled glass-making centers were flourishing in the first half of the 12 th century).

202 See, e.g., Stefano Carboni, Gregorio's Tale; or, Of Enamelled Glass Production in Venice,

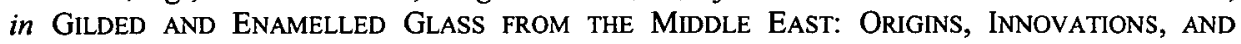
INFLUENCES 101, 101-06 (Rachel Ward ed., 1998) (describing how Gregorio, glass enameler in Venice from Byzantine territory of Morea, had been influenced by glass made by Muslim artisans); Hess, supra note 151, at 4, 7 (asserting that Eastern objects created local tastes that glassmakers tried to copy, and that a 15th-century manuscript from Bologna provides evidence that enameling in Venice was based on processes from the Islamic world); see also Hugh Tait, Venice: Heir to the Glassmakers of Islam or of Byzantium?, in ISLAM AND THE ITALIAN RENAISSANCE 77, 83 (Charles Burnett et al. eds., 1999) (acknowledging that on an artistic level, Venetians were striving to produce glass vessels similar to Islamic styles but concluding that evidence of Islamic technical influence on Venetian glassmaking is "negligible").

203 Tait, supra note 202 , at $79,83$.

204 Hess, supra note 151 , at 4.

205 For a detailed accounting of Byzantine trading with Egypt, see COMMERCLAL EXCHANGE, supra note 170 , at pt. I, 25-77.

206 Hess, supra note 151 , at 4.

207 Id. 
Ahsan al-taqāsim fi ma 'rifat al-aqālìm (The Best Divisions in the Knowledge of the Regions), that Muslims traveled through Constantinople for many reasons, including trade. ${ }^{208}$ Al-Muqaddasi also describes Muslim prisoners of war "employed in various works," such as building and artisanal crafts in Constantinople. ${ }^{209}$ Acknowledging that a profession would only increase the value and utility of a Muslim captive, Al-Muqaddasi notes of the prisoners that, "[t]he prudent man does not admit his occupation, when asked."210

Venice also had more direct ties to Arab states. As Constantinople's power declined, Venice began to maintain direct diplomatic and commercial relationships with Arab capitals. Introductory diplomatic missions frequently exchanged artisanal goods. ${ }^{211}$ By the 13th century, prominent merchants regularly traveled back and forth between Venice and the major ports of the Levant including not only Constantinople and the Crusader States, but also Damascus in Syria and Alexandria and Cairo in Egypt. ${ }^{212}$ Venice maintained consular offices in Alexandria, Damascus, Aleppo, and also Hama, Beirut, Tripoli, and Jerusalem. ${ }^{213}$ Merchants imported finished glass from Constantinople, Egypt, and Syria along with other valuable merchandise. ${ }^{214}$

Conquest played a role as well as trade. The capture of Jerusalem in 1099 under the First Crusade brought several prosperous Mediterranean cities, previously under Byzantine and then Arab control, under the sway of Europeans. In 1123 Venice had provided crucial naval support to the new Crusader state. ${ }^{215}$ King Baldwin II rewarded Venice with trading rights throughout the ports of the kingdom free from any tolls or customs, and portions of port cities of Tyre and Acre as Venetian quarters. ${ }^{216}$ These events inaugurated a period of robust trade between Venice and the Crusader cities of the Eastern Mediterranean. ${ }^{217}$ Soldiers and pilgrims brought back examples of

\footnotetext{
208 MuHammad ibn AHMad Al-Muqaddasi, The Best Divisions for the KNOWledge of THE REgIONS: A TRANSlation OF AHSAN AL-TAQASIM FI MA'RIFAT AL-AQAlim 147-48 (Basil A. Collins trans., 1994).

209 Id. at 147.

$210 \quad$ Id. at 148

211 AULD, supra note 178, at 49.

$212 \quad$ Id. at 47.

$213 \quad I d$.

214 See, e.g., Sylvia Auld, The Mamluks and the Venetians Commercial Interchange: The Visual Evidence, 123 PALESTINE EXPLORATION Q. 84 (1991).

215 MADDEN, supra note 163 , at 77.

$216 \quad I d$.

217 For detailed descriptions of this trade, see generally David Jacoby, The Trade of Crusader Acre in the Levantine Context: An Overview, in ARCHIVIo STORICO DEL SANNIO (n.s.) (1998) reprinted in COMMERCIAL EXCHANGE, supra note 170, at part IV, 103-20.
} 
Islamic and Byzantine luxury crafts and glassware that were treated as marvels in their home cities. ${ }^{218}$

Islamic luxury glass created a sensation when it was first imported into Europe. ${ }^{219}$ Venetians and most of Europe were fascinated by Eastern craft objects such as paper, porcelain, silk, and glass. These objects-more affordable than precious metals, but fine enough to denote status and discernment-were in great demand among the rising merchant families of Italy. With surplus income from trade, they could allow themselves the luxury of eating and drinking in higher style. ${ }^{220}$ The tradition of sharing dishes and utensils, still used in France and England at the time, was replaced in Venice by individual place settings, glasses, and flatware. ${ }^{221}$ Precious metals were too expensive for such everyday instruments, but porcelain and glass, relatively inexpensive in raw form, were the ideal materials to supply Italy's newly sophisticated tables. ${ }^{222}$

Gilded and enameled glass similar to that made in Byzantium and the Levant soon began to be produced in the workshops of Venice. ${ }^{223}$ The first known examples of fine enameled glass produced in post-classical Europe are Venetian vessel and vessel fragments signed with Italian names and dateable to the late-13th and early-14th centuries. ${ }^{24}$ These beakers are descended in color and appearance from Egypt and Syria ${ }^{225}$ and were made using techniques from Byzantium. $^{226}$

The elaborate techniques for making gilded and enameled glass required specialized training and years of practice with the underlying

\footnotetext{
218 Hess, supra note 151, at 6-11.

219 Id. at 5 . For a fuller description of European appreciation for Islamic glass and its impact on Venetian techniques, see Rosamund E. MaCk, BazAar to PIazza: Islamic Trade and ITALIAN ART, 1300-1600, at 113-23 (2002).

$220 \quad$ Hess, supra note 151 , at 28.

$221 \quad$ Id. at $23,26-27$.

$222 \quad$ Id. at 27.

223 Id. at 5, 17; Harden, supra note 193, at 328; Marco Verita, Analyses of Early Enamelled Venetian Glass: A Comparison with Islamic Glass, in GILDED AND ENAMELLED GLASS FROM THE MIDDLE EAST, supra note 202, 133 (finding that "Aldrevandin" beakers show extensive similarity with Islamic enameled glass including the quality of the glass, the method of preparing the enamels and the pigment identity).
}

224 Hess, supra note 151, at 5.

225 See Carboni, supra note 202, at 102 (hypothesizing that the inspiration for the Aldrevandin beakers was colored enamel glass made by the Saracens); Hess, supra note 151, at 5-7, 17 (comparing Italian Aldrevandin beakers with Byzantine bowl, 10th century, and "Luck of Edenhall" beaker from Syria, mid-13th century); Tait, supra note 202, at 78 (Aldrevandin beakers "mirror" an Islamic shape); Verita, supra note 223, at 133 (noting that techniques similar to those used in Islamic glassmaking were used to manufacture the Aldrevandin beakers).

See Tait, supra note 202 , at 83. 
ingredients. ${ }^{227}$ Local craftsmen could not have guessed at the methods simply from examining the products brought back from the Levant. ${ }^{228}$ The movement of glassmaking techniques required the migration of artisans. ${ }^{229}$ From exhaustive guild documentation in the Venetian archives, we know that several glass enamellers working in Venice at the time came from areas formerly within the Byzantine Empire, where they would have received their training. ${ }^{230}$ These craftsmen, in turn, were influenced by the styles prevalent in Syria and Egypt. ${ }^{231}$

Gregorio di Napoli and Bartolomeo of Zara, two glass enamellers mentioned prominently in the Venetian guild archives from the late $1200 \mathrm{~s}$, both came from former Byzantine territories. ${ }^{232}$ The most likely explanation for the appearance of Byzantine-trained workers in Venice in the mid-1200s is the sack of Constantinople led by Venice as part of the Fourth Crusade in $1204{ }^{233}$ Under the pretext of overthrowing a tyrant usurper, the powerful Venetian armada attacked Constantinople in $1203 .^{234}$ The city and her riches fell to Venetian control, and all of the formerly Byzantine territories along the Adriatic Coast became vassal states of Venice. ${ }^{235}$

Gregorio had come from Morea, a region of the Peloponnese. ${ }^{236}$ Archeological records suggest that two large glass factories operated in

\footnotetext{
227 LoNG, supra note 73, at 90; McCray, supra note 89, at 306-09.

228 See Hess, supra note 151, at 13; Pamela Long, Invention, Secrecy, and Theft: Meaning and Context in the Study of Late Medieval Technical Transmission, 16 HIST. \& TECH. 223, 225 (2000).

229 See Hess, supra note 151, at 13; cf. Walterscheid, supra note 134, at 866 (noting that even in 18th-century American entrepreneurs were not able to import textile or other manufacturers without also encouraging the immigration of skilled artisans); GLICK, supra note 181, at 271 (noting that the spread of technology across Muslim and Christian Spain depended upon the migration of artisans).

230 See Carboni, supra note 202, at 101-04; Hess, supra note 151, at 5; Tait, supra note 202, at 80 .

231 Hess, supra note 151, at 5-7, 17; see also Tait, supra note 202, at 77, 83 (acknowledging that on an artistic level, Venetians were striving to produce glass vessels similar to Islamic styles). See generally Carboni, supra note 202, at 101-06.

232 Carboni, supra note 202, at 101-02; Tait, supra note 202, at 80.

233 Seth C. Rasmussen, How Glass Changed the World: The History and Chemistry of GLASS FROM ANTIQUITY TO THE 13TH CENTURY 42 (2012).

234 Madden, supra note 163, at 138-39.

235 Id; see also Jacoby, Changing Economic Patterns in Latin Romania: The Impact of the

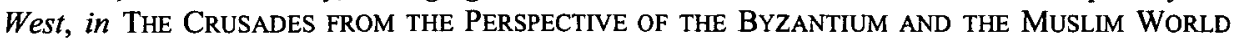
(A.E. Laiou \& R.P. Mottahedeh eds., 2001), reprinted in COMMERCIAL EXCHANGE, supra note 170, at part IX, 228-29.

236 Carboni, supra note 202, at 101; Tait, supra note 202, at 80.
} 
Corinth, the capital city of the Peloponnese in the 11 th or 12 th century. ${ }^{237}$ Historians disagree about whether the Corinth factories employed Byzantine or Egyptian techniques. ${ }^{238}$ (As Egypt was part of Byzantium before the Arab Conquest, the techniques may have a common root). ${ }^{239}$ Nonetheless, these 12th-century installations seem to have formed a way-station by which eastern techniques migrated west to Italy. ${ }^{240}$ Gregorio's training in glass enameling techniques probably came by way of dissemination of the techniques established at Corinth. ${ }^{241}$ Bartolomeo had come by way of Zara, a Byzantine city on the Dalmatian Coast also sacked in 1203 by the Venetian Armada. ${ }^{242}$ Both masters imported techniques from their home territories, midway points between the Eastern and Western Mediterranean, into Venice. ${ }^{243}$

Conquest and fear of invaders also prompted artisan emigration to Venice. The success of the Crusader enterprise along the Eastern Mediterranean was short-lived. By 1188 Jerusalem fell to the Arab general Saladin. In 1291, the last Crusader citadel fell in Acre. The Knights of the Teutonic Order, sworn defenders of Acre, retreated to Venice and established a temporary headquarters there. ${ }^{244}$ Many Venetians who had moved to the Venetian quarter of Tyre to conduct business in the other Levant cities were welcomed back. With them came many children of Venetian fathers and Syrian mothers who may well have learned skills such as glassmaking from their families in the East. ${ }^{245}$

237 There is some debate as to whether the factories survived and continued to produce into the 13th and 14th centuries. See, e.g., David Whitehouse, Glassmaking at Corinth: A Reassessment 75-77 (Association Française pour l'Archéologie du Verre 1989), http://afaverre.fr/pdf/ Actes_1989/10_Whitehouse-actes_1989.pdf (last visited Oct. 8, 2015).

238 Harden, supra note 193, at 328.

239 See, e.g., Tait, supra note 202, at 79 (concluding that Venetian and Islamic glass-making both derived from Byzantine practices).

240 Harden, supra note 193, at 328; RASMUSSEN, supra note 233, at 40 .

241 But see Carboni, supra note 202, at 101 (hypothesizing that Gregorio had learned his skills by traveling to Saracen territories).

242 Carboni, supra note 202, at 102.

243 Whitehouse has advanced the possibility that the glassmaking factories at Corinth were run by Italians and had no connection to Egyptian or Byzantine precedents. Whitehouse, supra note 237 , at 78 . However, this is merely conjecture, and no follow-up studies have supported this thesis.

244 Carboni, supra note 202, at 103.

245 AULD, supra note 178, at 38. Some accounts also mention a treaty between Bohemond VII, Crusader King of Antioch, and Venice in 1277 promising to send Syrian glassmakers to teach Venetians their secrets. RASMUSSEN, supra note 233 , at 42 . Others claim the treaty simply imposed a tax on the import of glass cullet from the Crusader Levantine ports. See generally Carboni, supra note 202, at 101-02. The Author has been unable to locate the original text of the treaty in my sources. 
The fear of invasion by the Mongols also pushed artisans towards Venice. By 1260 Mongol armies had conquered Baghdad and Kiev and had been menacing cities as far west as Hungary and Damascus. It was Mongol practice to gather skilled artisans in conquered territories and ship them back to the Khan capitals to supply the armies and enrich life at court. ${ }^{246}$ Many Arab craftspeople fled west to North Africa or Islamic Spain in advance of the onslaught. ${ }^{247}$ Skilled glassmakers from the Black Sea and Eastern Mediterranean similarly might have preferred to emigrate with their families to Venetian territories rather than face the threat of bondage under the Mongol rulers. ${ }^{248}$

Monks, who at this time could travel freely between monasteries in Eastern and Western Christendom, were another vehicle for the transmission of craft knowledge from East to West. Sometime in the early 12th century, Theophilus Presbyter, a Benedictine monk in Germany wrote De Diversis Artibus, a handbook of various crafts as practiced by the Byzantine Greeks of the time. ${ }^{249}$ Theophilus had traveled to Constantinople and had evidently remained there for some time pursuing training in various arts. ${ }^{250}$ His purpose in writing the treatise was to train his brothers, and it is likely that he himself practiced as a metalsmith in Germany. ${ }^{251}$ The Benedictine Order as a whole prized daily creative labor as undertaken in "cooperation with God." 252 As outposts of this Order spread quickly throughout Western Europe during the 10th century, they may have played an important role in nurturing and spreading craft techniques such as glassmaking. ${ }^{253}$ Indeed, records from the founding of a Benedictine monastery in Venice in 1063 note the presence of

\footnotetext{
246 Weatherford, supra note 158 , at 112, 135, 169-70.

247 See, e.g., AsHTOR, supra note 114 , at $288-89$ (noting the migration of artisans from Iraq to Egypt and Syria in advance of the Mongol armies); GLICK, supra note 181, at 271-72 (Persian potters fled to Andalusian Spain at the end of the 13th century to escape the Mongol conquests).

248 In 1401, under Tamerlane, a Mongol force did sack Damascus, a flourishing capital of glass production, and packed off the city's skilled artisans to their capital at Samarqand. It is possible that some artisans fled in advance of these battles, though specific historical records are scarce. See Hess, supra note 151, at 7 (advancing this theory).

249 See Tait, supra note 202, at 80 . This work has been translated by various authors. See, e.g., THEOPHILUS, AN ESSAY UPON VARIOUS ARTS IN THREE BOOKS (Robert Henrie trans., John Murray 1847), https://archive.org/stream/theophiliquietr0lhendgoog\#page/n6/mode/2up (last visited Oct. 8, 2015).

250 See TheophiLus, supra note 249, at 117 (Preface to the Second Book).

251 Tait, supra note 202, at 80; THEOPHILUS, supra note 249, at 117 (instructing his brothers in glass arts used in the Hagia Sophia in Constantinople).

252 See KAUFER, supra note 40, at 2.

253 E. Juárez Valero, Secreto y Monopolio En Venecia: El Gremio del Vidrio Muranés, [Secrecy and Monopoly in Venice: The Guild of Glassmakers in Muran] 51 BOLETIN DE LA SOCLEDAD ESPAÑola DE CERÁMICA Y VIDRIO 285, 286 (2012) (Spain).
} 
Dominic "Fiolare," or maker of glass vials. ${ }^{254}$ This is the first mention of a glass artisan in the existing Venetian archives. ${ }^{255}$

We also know that the abbot of the Benedictine Monastery at Monte Cassino, south of Rome, sent several monks to Constantinople some time after 1066 to hire expert Byzantine mosaicists, (workers in colored glass, stone, and porcelain) for the decoration of the newly rebuilt abbey church. ${ }^{256}$ According to chronicler Leo of Ostia, the Greek artists journeyed to Italy and their work was much admired. The abbot then decided that the Greeks should train the young monks in the monastery. ${ }^{257}$ If these kinds of transfers existed for mosaic work, it is possible that similar transfers took place for training in glass working and enameling.

Some historians claim that Venetian merchants took craftsmen to the Levant with them to work alongside Arab masters in their workshops, though no contemporaneous record of this practice is known. ${ }^{258}$ Venetian merchants apparently stayed in North Africa and Syria for long stretches while on trading runs. $^{259}$ At the end of the 12th century, Leonardo Fibonacci, the son of an Italian merchant from Pisa resided for many years in North Africa where he famously learned and brought back the "Arabic" numeral system that finally replaced Roman numerals in trade. ${ }^{260}$ Niccolo Marcello, who became Doge of Venice in 1473, had been an important merchant based in Damascus for many years. ${ }^{261}$ Artisans evidently traveled as well. Diplomatic records mark the presence of Batholomeo de Bartholmeis, a Venetian jeweler, at the arrival of a new consul in Damascus. ${ }^{262}$ If the accounts of training in local workshops are accurate, such contact might have provided more direct opportunities for migration of Islamic glass techniques to Venice. ${ }^{263}$

By 1271 , the time that the first glass guild rules were recorded, Venice was experiencing an influx of craftsmen and methods from the East, via the

$$
\begin{array}{ll}
254 & I d . \\
255 & I d .
\end{array}
$$

256 Thomas Jex Preston Jr., The Bronze Doors of the Abbey of Monte Cassino And of St PaUl's Rome 9-10 (1915).

257 Id. at 9 n. 16.

258 AULD, supra note 178, at 38 (quoting H. Lavoix, Les Azziministes, GAZETTE DES BEAUX ARTS, Jan. 1, 1862, at 64, 67).

259 See David Jacoby, The Migration of Merchants and Craftsmen: A Mediterranean Perspective (12th-15th Century), in LE MIGRAZIONI IN EUROPA SECC. XIII-XVIII (Simonetta Cavaciocchi ed., 1994), reprinted in TRADE, COMMODITIES AND SHIPPING IN THE MEdiEval MEditerRaNEAN 548-49 (1997) [hereinafter Jacoby, TradE, CoMMODITIES AND SHIPPING].

260 Singer, supra note 137 , at $766-67$.

261 AULD, supra note 178 , at 47.

262 Id.

263 But see Tait, supra note 202, at 79 (concluding that the sophisticated techniques of Islamic glass-blowers were never imported into Italy). 
territories of Greek Byzantium and possibly, directly from Syria and Egypt as well. ${ }^{264}$ From gateway cities such as Venice and Genoa, techniques spread rapidly to neighboring Italian jurisdictions through the migration of locally trained artisans.

The eagerness of the developing cities of Northern Italy and Europe to assimilate this knowledge is illustrated by the open invitations issued proactively at roughly the same time all along the Eastern frontier of Western Europe. These laws gave general permission to foreign artisans, meaning those from a different city, to settle and practice their trade. ${ }^{265}$ For example, in Bologna in 1315, the community promised

that persons skilled in certain arts have come to our town and continue to come daily, where they hope they may stay quietly and safely and exercise their art and trade; and they have begun to exercise and teach such arts ... whereby great honor and gain will come to our community and its citizens ... . ${ }^{266}$

In some cases the cities encouraged resettlement by artisans through the granting of privileges such as financial aid, tax reduction, or protection from foreign creditors. ${ }^{267}$ Records exist of similar laws in Florence in 1314, in Venice in 1320, and in German cities of the same period. ${ }^{268}$ These permissions assume a certain inflow of artisans and aimed both to influence their choice of residence and encourage open sharing of new techniques with local guild members.

The earliest regulations of the Venetian glass guild, from 1271, demonstrate not only the stirrings of the idea of craft knowledge as proprietary, ${ }^{269}$ but also a keen competition between cities to attract skilled artisans. The import of new technologies required inducement of individual immigrant craftsmen. Special privileges did not themselves cause artisans to migrate; large scale Western migration was happening in any case due to larger military, political, and economic forces. But because artisans had a choice of city-states, competition among the handful of gateway cities in Italy and Germany led communities to offer benefits to individual residents. Once a new industry had been established, the cities sought to keep their competitive advantage by forbidding artisans from emigrating out. The penalties for

\footnotetext{
264 Hess, supra note 151, at 7, 13; AULD, supra note 178, at 38-39.

265 See Jacoby, TRADE, COMMODITIES AND SHIPPING, supra note 259, at 533, 550-59 (describing the migration of skilled artisans throughout medieval Europe in the 13th through 15th centuries).

266 Prager, supra note 3, at 119 (citing to 7 G. Livi, ARCH. STOR. ITAL. 29 (1881)).

267 Id.

268 Id. at 118-23; see Hulme, supra note 9, at 142.

269 LoNG, supra note 73, at 89-90; McCray, supra note 89, at 309, 316.
} 
emigration contained in the 1271 guild laws were one method that gateway cities, like Venice, used to stop newly trained apprentices from taking hardwon techniques elsewhere. ${ }^{270}$ The new appreciation for urban craft techniques evinced by these guild regulations arose because of competition for foreign craft knowledge among the emerging trading republics of easternmost Latin Europe.

The connection between Eastern migration and the guild and privilege laws in 14th-century Italy is also demonstrated by the lack of similar rules at the frontier of Islamic and Christian Spain at the same period. Islamic Spain in the 12 th and 13th centuries was known as an important center for silk, paper, and ceramic production. As Christian leaders re-conquered territories from Muslim rule, they tried to keep Islamic craft centers intact. Unlike in Italy, however, artisans with the necessary skills were already present; the trick in reconquered Spain was to keep them from leaving. Therefore, Christian leaders made concerted efforts to retain Eastern crafts by protecting established artisanal communities from competition. ${ }^{271}$ They also offered royal or seigniorial privileges to specific groups of Muslim workers willing to resettle in Christian Spain as a way to develop particular industries. ${ }^{272}$

No general privilege system appeared aimed at encouraging the migration of other Europeans, however, as would be expected if the technological revolution of the time was mainly internal to the Latin West. There was also no need for open legal inducements; the territory was all under the control of one ruler, and individual towns were discouraged from competing with one another. ${ }^{273}$

\section{B. Early Municipal Proto-Patents Covered Irrigation, Dredging and Milling Technology that Likely Diffused to Europe from Andalusian Spain and the Levant}

The second forerunner of patent privileges-the patronage and monopolies given to importers of new water technology-also seems to have been influenced by contact with the Eastern Mediterranean and Islamic Spain. In Venice, as in many medieval states, rulers awarded periodic privileges, or "grazie," to individuals in return for service to the republic. ${ }^{274}$ Grazie could take many forms - payment for loyal service or tax relief to favored merchants, for example-but in the mid-13th century, a new form of privilege began to appear

\footnotetext{
270 See LONG, ORIGIN OF PATENTS, supra note 73, at 873-75 (describing futile efforts by the Venetian glass guild to prevent craft knowledge from leaving the city).

271 See generally GLICK, supra note 181, at 252.

$272 \quad I d$.

$273 \quad$ Id.

274 Mandich, supra note 17 , at 2.
} 
in Western Europe. ${ }^{275}$ These new privileges rewarded those who opened new mines, dredged rivers, built mills, or brought new engineering tools or techniques not before used in local markets. ${ }^{276}$

The majority of the early industrial privileges in Venice were for watermilling and dredging devices, suggesting a new focus on planned municipal development and more intensive uses of waterpower. ${ }^{277}$ In 1936, when the 1474 Venetian statute was first unearthed, historical consensus agreed that widespread use of watermills and industrial milling technology were a hallmark of a uniquely European "exploratory attitude" toward forces of nature that earlier societies had lacked. ${ }^{278}$ This consensus was based primarily on examination of classical and European documentary and artistic sources. ${ }^{279}$

The weight of historical evidence no longer supports this view. Since the $1960 \mathrm{~s}$, a growth of interdisciplinary approaches has led to reexamination of the ancient and medieval periods through more empirical and systematic approaches. ${ }^{280}$ These include fields such as economic history, environmental history, and archeology. ${ }^{281}$

This new research demonstrates that hydraulic technology had been steadily diffusing through Eurasia since antiquity. ${ }^{282}$ Archeological research from the last few decades has revealed that use of waterpower under the Romans was more extensive than earlier believed. ${ }^{283}$ Use of vertical watermills appears to have been widespread both for grinding grain and for more industrial uses such as sawmilling. ${ }^{284}$

Roman installations fell apart in Western Europe after the fall of the Empire, ${ }^{285}$ but the eastern territories of Egypt, Syria and Persia largely

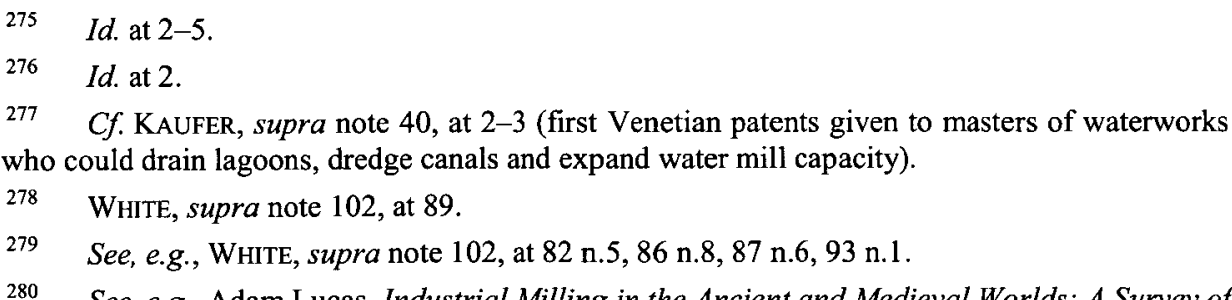

280 See, e.g., Adam Lucas, Industrial Milling in the Ancient and Medieval Worlds: A Survey of the Evidence for an Industrial Revolution in Medieval Europe, 46 TECH. \& CULTURE 1, 8, 24 (2005) (describing how new archeological and economic research has undermined conclusions about industrial watermilling reached through anecdotal archival research).

$281 \quad$ Id.

282 Thomas Glick, Comment on Paper by Watson, 34 J. ECON. HIST. 74, 77 (1974).

283 Michael Lewis, Millstone and HaMmer: THE ORIGINS OF Water Power (1997); Örjan Wikander, The Water-mill, in HANDBOOK OF ANCIENT WATER TECHNOLOGY 371-400 (Örjan Wikander ed., 2000).

284 AdAm LuCAS, Wind, Water, Work: Ancient and Medieval Milling Technology 208-09 (2006).

285 See, e.g., Daniel G. Curtis \& Michele Campopiano, Medieval Land Reclamation and the Creation of New Societies: Comparing Holland and the Po Valley, c.800-c.1500, 44 J. HIST. 
conserved the technology. ${ }^{286}$ After the Arab conquest, a diffusion of new crops and agricultural technology from India and Persia that had begun in Roman times accelerated. ${ }^{287}$ These tropical cultivars required more intensive uses of irrigation techniques in arid Arab lands. ${ }^{288}$ Persians and later Arabs adapted Roman and other ancient hydraulics and also incorporated techniques inaugurated by the Chinese. ${ }^{289}$ Regardless of who pioneered the techniques, in the late medieval period these hydraulic innovations diffused to Europe via neighboring Arab lands.

From the 8th century onwards, the territories under Arab rule show sustained activity in the building and maintenance of irrigation systems. ${ }^{290}$ The old Roman waterworks of antiquity were revived, enlarged, and expanded. New waterways were dredged. ${ }^{291}$ Watermills and waterwheels were an integral part of this technology, in some places forming part of elaborate installations for raising water and irrigating extensive networks of canals. ${ }^{292}$

The sophistication of Arab hydrology during this period has led historians to reevaluate the thesis that Medieval Europe alone began to appreciate the power of water on a large scale. Archeological work in Iberian Spain shows the clear presence of vertical water wheels used to raise water

GEO. 93, 95 (2014) (describing the deterioration of Roman waterworks in Italy's Po Valley after the 6 th century C.E.).

286 See, e.g., Meron Benvenisti, The Crusaders in the Holy Land 263-67 (1970) (describing the Roman water supply systems still in use in Syria at the time of the Crusades). Benvenisti inexplicably attributes decline in the water installations to their time under Arab rule, even though the waterworks had been under Arab dominion for 300 years by the time of the Crusades and, as he relates, were mostly still in working order. Id.

287 Andrew M. Watson, Arab Agricultural Revolution and Its Diffusion, 700-1100, $34 \mathrm{~J}$. ECON. HIST. 8 (1974). These crops included rice, sorghum, sugar cane, cotton, watermelons, eggplants, spinach, artichokes, colocasia, sour oranges, lemons, limes, bananas, plantains, mangos, and coconut palm. Id. at 8-14.

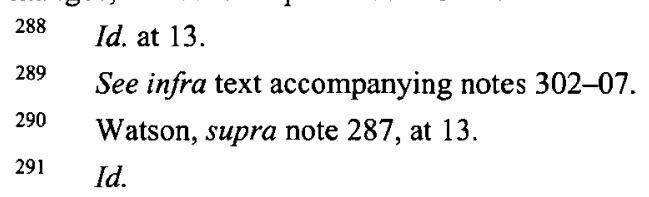

292 See TERry Reynolds, STRONGER than a Hundred MEN: A History of the Vertical Water Wheel 117-19 (1983); see also AhMAD Y. Al-HASSAN \& Donald R. HiLl, ISLAMIC TECHNOLOGY: AN IlLUSTRATED HISTORY 54 (1986); AL-MUQADDASI, supra note 208, at 125, 164-65, 174, 320; Michael Harverson, Watermills in Iran, 31 IRAN 149, 150 (1993); Donald R. Hill, Information on Engineering in the Works of Muslim Geographers, 9 HIST. TECH. 127, 136 39, reprinted in STUdies IN MEDIEVAL ISLAMIC TeCHNOLOGY: FroM PHILO TO AL-JAZARī-FROM ALEXANDRIA TO DIYĀr BAKR, at pt. VI, 136-39 (David A. King, ed., 1998); LuCAS, supra note 284 , at $210-11,216,230$ (noting that uses of waterwheels for purposes beyond grinding grain or malt did not begin in Europe until the late 10th or 11 th century). 
levels and power irrigation systems. ${ }^{293}$ Some of these hydraulic irrigation techniques diffused into Europe via Islamic Spain. ${ }^{294}$ For example, the earliest irrigation installations in medieval France resemble the Iberian models. ${ }^{295}$

Not only irrigation, but water-powered manufacturing techniques diffused to Western Europe as well. A main source for transfer of some of this technology was the Crusader cities of the Eastern Mediterranean. After assuming control of many of the cities along the Syrian coast, the Crusader forces inherited and extended existing irrigation and milling installations. ${ }^{296}$ Many of the canals had been built in Roman times but had been used and repurposed under later Byzantine and Arab rule. ${ }^{297}$ In addition, new uses of water wheels and water milling had been introduced under the Arabs in the form of sugar mills. ${ }^{298}$ These used waterpower to grind and press sugar cane as part of a complex process of distillation and manufacture. ${ }^{299}$ The Crusader forces, especially the resident knightly orders of the Templars and the Hospitallers, recognized the value of sugar production and quickly assimilated sugar growing and processing techniques. ${ }^{300}$ After the Crusaders were expelled from the Levant in 1291, the Templars and Hospitallers built new grain and sugar milling installations in their new fiefdoms on Cyprus and Rhodes. ${ }^{301}$

Another water-powered innovation that appeared around this time was the use of water-powered trip hammers for pounding pulp in making paper and

293 LUCAS, supra note 284, at 211; Thomas F. Glick \& Helena Kirchner, Hydraulic Systems and Technologies of Islamic Spain: History and Archaeology, in 3 WORKING WITH WATER IN Medieval Europe: TeChNology and ResourCe-Use 311 (Paolo Squatriti ed., 2000).

294 See GLICK, supra note 181, at 219, 226-27, 235-38 (noting the multiplicity of 'hydraulic devices' that diffused from East to West during the medieval period); Glick \& Kirchner, supra note 293, at 317; Donald Hill, A History OF ENGINEERING IN Classical AND MEdiEval TiMES 7 (1997); Watson, supra note 287, at 20-23; Donald R. Hill, Andalusian Technology, in STUDIES IN Medieval Islamic Technology: From Philo to al-Jazarī-From AleXandria to DiYãR BAKR, supra note 292, at pt. XVIII, 237.

295 Paul Benoit \& Josephine Rouillard, Medieval Hydraulics in France, in WORKING WITH WATER IN MEDIEVAL EuRope: TeChNOLOGY AND ResourCe-Use, supra note 293, at 176 (describing how irrigation systems in medieval France were "very similar" to those in the Iberian world).

296 BENVINISTI, supra note 286, at 247-52, 263-67.

297 Id.

298 PACEY, supra note 142, at 10.

299 BENVINISTl, supra note 286, at 254-56; Hamdan Taha, Some Aspects of Sugar Production in Jericho, Jordan Valley, in A TIMELESS VALE: ARCHAEOlogICAL AND Related EsSAYS ON THE JORDAN VALLEY N HONOUR OF GERRIT VAN DER KOOIJ ON THE OCCASION OF HIS 65TH BIRTHDAY 181-91 (Eva Kaptjin \& Lucas P. Petit eds., 2009).

300 BENVINISTI, supra note 286, at 253; Taha, supra note 299, at 181.

301 David Jacoby, The Venetians in Byzantine and Lusignan Cyprus: Trade, Settlement, and Politics, in Venice In CyPrus ANd CyPrus IN VenICE 74 (Angel Nicolaou-Konnari ed., 2009). 
for husking rice. ${ }^{302}$ These mills encompassed a standard vertical watermill coupled with the use of trip hammers to pound flax or linen pulp. The trip hammers would rise and fall in response to a cam, or projection, on the axle of the water wheel. The cams and grooves translated the rotary motion of the waterwheel to the vertical pounding of the hammers. ${ }^{303}$

Water-powered cam and trip hammer mills were used in China for crushing grain, ore, rice, and sugar cane since at least the 1 st century B.C.E. ${ }^{304}$ In 751 C.E., Chinese prisoners of war introduced paper making to the Islamic world in Samarqand. ${ }^{305}$ It is assumed, but not proven, that the techniques of making paper using water-driven mills were also transferred at this time. ${ }^{306}$ This technology, identical for paper making or rice-husking, is thought to have diffused together with these commodities from Asia westward through Islamic

\author{
302 PACEY, supra note 142 , at 10. \\ 303 LUCAS, supra note 284 , at 233-34. \\ 304 Id. at 209 (citing 4 Joseph NeEdhaM, SCIENCE AND Civilization IN China 370,392 \\ (1965)).
}

305 See AL-HASSAN \& HILL, supra note 292, at 191; PACEY, supra note 142, at 41; HANS E. Wulff, The Traditional Crafts of Persia: Their Development, Technology, and INFLUENCE ON EASTERN AND WESTERN CIVILIZATIONS 236-37 (1966). For a description of the spread of paper-making through the early Islamic Empire, see JONATHAN BLOOM, PAPER BEFORE PRINT: THE HISTORY AND IMPACT OF PAPER IN THE ISLAMIC WORLD 46-89 (2001).

306 GLICK, supra note 181, at 266-67, 279, 242; BLOOM, supra note 305, at 54-56; HILL, supra note 294, at 10, 172 (1997) ("The balance of probability, however, is in favour of the technology having been developed in Islam after the period of expansion and consolidation had been completed about the middle of the eighth century, and of a fairly slow diffusing of industrial milling throughout the Muslim world during the ensuing centuries."); WULFF, supra note 305, at 236-37. But see REYNOLDS, supra note 292, at 119 (1982) (asserting that "[t]he use of waterpower in the Islamic world seems to have been confined to two tasks-grinding grain and raising water"); Robert I. Burns, The Paper Revolution in Europe: Crusader Valencia's Paper Industry-A Technological and Behavioral Breakthrough, 50 PACIFIC HIST. REV. 1, 13-19 (1981) (arguing that Muslim papermakers in Spain used hand-operated presses and Christians were the first to use hydropower in manufacturing paper in Spain). The best evidence for water-powered paper mills in the medieval Middle East comes from a text on metallurgy by al-Binuni (973-1048 C.E.) who relates that gold-bearing ores were crushed by stones attached to hammers in flowing water for pounding purposes, as in Samarqand, with the pounding of flax is ground for making paper. BLOOM, supra note 305, at 55-56; see also Eliyahu Ashtor, Levantine Sugar Industry in the Later Middle Ages: An Example of Technological Decline, in TECHNOLOGY, INDUSTRY AND TRADE, supra note 103, at pt. III, 268-69 (stating that some Islamic paper mills used water power and hypothesizing that the better quality of later European paper was due to the introduction of iron spikes attached to the wooden stampers). 
trading routes. ${ }^{307}$ Similar mills first appear in French and Christian Spanish sources in the 11 th and 12 th centuries. ${ }^{308}$

In the late 13th century, at a time of expanded commerce and immigration from the Arab East, more sophisticated water technologies started proliferating around Venice as well. The records of the Great Council of Venice from 1281-1296 reveal a new variety of privileges for innovative uses of dredging tools and waterpower on public lands and waterways. ${ }^{309}$

Beginning in 1416, the first industrial patents similar to those used in the modern age appear in Venice. In that year the Archives reveal that Franciscus Petri from Rhodes offered to build mills using pestles (triphammers) to full cloth at his own expense. ${ }^{310}$ Petri promised that the mills would be superior to the ones existing in Venice and would produce finer cloth for the same price as currently paid by Venetian wool weavers. Most significantly, he posed the condition that "no one, except for he himself and his heirs or successors, in the city of Rivalto or within ten miles, can build or have them built fulling mills for the next 50 years, which are similar to his." 311 The Great Council of the Senate approved the grant, as Petri's activity was a novelty for Venice and useful for the city. ${ }^{312}$

Petri's patent for a cloth-fulling mill thus marks a turning point in Europe, from the use of patronage to encourage mechanical works to the grant of monopolies over new devices. ${ }^{313}$ This innovation was Petri's suggestion. The archives offer little further information about the origin of his new fulling technique or the inspiration for the new form of privilege.

307 BLOOM, supra note 305, at 54-56; GLICK, supra note 181, at 233-34, 242; HiLL, supra note 306, at 10; Glick \& Kirchner, supra note 293, at 311-12; see also WULF, supra note 305 , at 290-91 (describing traditional methods for rice-husking using water power in the Caspian provinces of historical Persia).

308 LUCAS, supra note 284, at 229, 238-39 (discussing some of the debates about when hydraulic powered trip hammers first appear in Europe).

309 Mandich, supra note 17, at 7. Prager gives an earlier date of "before 1200 " for the first of these grants, and says they were controlled by the "General Welfare Board." Prager, supra note 3, at 124-25. In his earlier article, Mandich explains that patent supplications were filed with the Senate, who then determined which group of magistrates would consider the matter. Mandich, supra note 2, at 185-86.

310 Mandich, supra note 17, at 16. See the translation in Giulio Mandich, Venetian Origins of Inventors' Rights, 42 J. PAT. OFF. SoC'Y 378, 379 n.6 (1960) (mentioning pestles).

311 Mandich, supra note 17, at 16.

312 Id.

313 An important caveat is that feudal lords and monastic orders commonly possessed seigneurial rights of monopoly over mills built on their land, and could compel their villeins to use these mills. Bloch, supra note 118, at 152; NoRTH \& ThOMAS I, supra note 7, at 27 . In these cases however the monopoly was based on ownership and dominion over the territory, not a limited right based on the introduction of new technology. See id. 
Fulling is the fourth and final step in the preparation of cloth. ${ }^{314}$ After combing, spinning, and weaving, fulling comprised beating or compressing the cloth in water. This shrank the cloth, strengthening it and giving it a firmer and smoother "felted" finish. ${ }^{315}$ Use of various detergents such as urine or manure further helped to cleanse and refine the cloth. ${ }^{316}$ Prior to the introduction of mechanized fulling, the work had traditionally been done by hand or foot inside a large trough. ${ }^{317}$

The use of water-power mills to full cloth appears to have been invented by Europeans inspired by exposure to the cam and trip-hammer mills used to pound paper, rice, and sugar in the Levant and Islamic Spain. ${ }^{318}$ The

\section{4}

Eleanora M. Carus-Wilson, An Industrial Revolution of the Thirteenth Century, 11 Econ. HIST. REv. 39, 39-40 (1941).

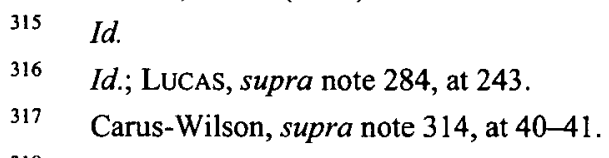

318 An enormous historical debate exists over whether water-powered fulling originated in the Middle East or Europe. Compare Hill, supra note 292, at 138 (stating that water-powered clothfulling existed in Persia in the 10th century), and HiLL, supra note 294, at 10 (same); LuCAS, supra note 284, at 211, 229 (repeating Hill's claim), and PACEY, supra note 142, at 10 (same), with REYNOLDS, supra note 292, at 119-21 (arguing that evidence for use of industrial milling in the medieval Islamic world is "inadequate"), and Eliyahu Ashtor, Economic Decline in the Medieval Middle East, 15 ASIAN \& AFRICAN STUD. 253, 273 (1981), reprinted in TECHNOLOGY, INDUSTRY AND TRADE: THE LEVANT VERSUS EUROPE, 1250-1500 (1992) (stating that waterpowered fulling mills were not adopted in the medieval middle East). A review of the original sources conducted for this Article suggests that Hill's claim, on which the rest of the pro-Islamic sources are based, rests on an overly optimistic translation of an alleged reference to waterpowered fulling by Al-Muqaddasi. See HILL, supra note 292, at 138 (citing to AL-MUQADDASI, supra note 208, at 409). The cited page is not contained in any of the existing partial translations, but I obtained a translation of the relevant text from Professors Adam Talib and Amina Elbendary, and it does not support Hill's claim about water-powered fulling. The relevant text states the following about the medieval Persian city Tustar:
You will find no better, no safer, no richer [place than this] in this clime. The river encircles it and [its water] encircles the fruit orchards and palm orchards. It is the source of anyone talented in making brocade and cotton.... You find good/proper markets and many specialities that people seek from East and West, they have cool water running under ground, yet their mosque is pleasant, the heat there is strong, their bridge is long and there is no other way besides it, often curiosities arrive to its markets.... the mosque is in the middle of the markets, in the Bazzazin section/cloth sellers market, and at the gate of the town is another market for cloth. And by the bridge there is an clear place where the qassarun/fullers are.

AL-MUQADDASI, supra note 208, at 409. According to Elbendary and Talib, the reference to "fullers" in the text most likely refers to people beating cloth, rather than to machines or mills. Email from Amina Elbendary, Assistant Professor of Arab and Islamic Civilizations, Am. Univ. at Cairo, to L.R. Bradford, Intellectual Prop. Counsel \& Research Fellow in Law, Am. Univ. in Cairo, and Adam Talib, Assistant Professor of Classical Arabic Literature, Am. Univ. in Cairo (Apr 7, 2014, 2:39 GMT) (on file with author). The evidence for medieval European use of fulling mills is considerable. See REYNOLDS, supra note 292, at 82 (describing the earliest 
technology used in medieval fulling mills is the same cam and trip-hammer technique believed to have been used in at least some Eastern paper-making and rice-hulling installations. ${ }^{319}$ The use of wooden hammers to pound sugar cane is also reported in medieval Syria and Egypt at the time of the Crusades, though the gearing was usually turned by animal rather than waterpower. ${ }^{320}$ The first fulling mills in Europe appear in Catalonia, Spain, just after Christian reconquest of these territories from Arab rule. ${ }^{321}$ Western Europeans, with access to more plentiful water resources, appear to have modeled early fulling mills on the animal and water-powered industrial mills of Spain and Syria. ${ }^{322}$

Petri came to Venice from Rhodes, a Greek island located in close proximity to modern Syria and the Anatolian peninsula. Since the fall of Rome, Rhodes had been variously a province of the Byzantine Empire, and, at times, under the control of Muslim forces. Since 1306 it had been the stronghold of the Knights Hospitallers, one of the orders formerly responsible for administering the territories of the Crusader Levant. ${ }^{323}$ To the extent Petri's device represented an innovation in cloth manufacture, it was an innovation that arose out of a mix of classical, Byzantine, Arab, and Frankish influences, and was not native to Venice or Italy.

As far as we know, Petri's patent was the only grant of its kind in Venice for some time. ${ }^{324}$ Then, it short order between 1444 and 1450 , three new patent "monopolies" were granted to foreigners. ${ }^{325}$ Between 1453 and 1474 , further monopoly patents were offered to builders of canons, mills, a

documentary evidence for European fulling mills); LUCAS, supra note 284, at 244-47 (describing historical evidence of early fulling mills in Europe); see also Carus-Wison, supra note 314 (discussing fulling mills in medieval England). However, the constituent technologies and knowhow for undertaking water-powered fulling were certainly present in the medieval Islamic world. REYNOLDS, supra note 292, at 119-20 (noting that based on the evidence of mills and hydropower dams in medieval Muslim lands, Islamic technicians were "fully capable of building water-powered industrial plants" and hypothesizing that they relied to a greater extent on animal power because of competing demands for water for irrigation purposes).

319 See GLICK, supra note 181, at 275-76 ("The prototype of the common tilt hammer fulling mill was the Chinese rice husking mill.").

320 See Ashtor, supra note 103, at pt. III, 247.

321 HILL, supra note 294, at 172; see GLICK, supra note 181, at 276.

322 REYNOLDS, supra note 292, at 117-20.

323 Anthony Luttrell, Feudal Tenure and Latin Colonisation at Rhodes:1306-1415, 85 ENG. Hist. REv. 755, 755 (1970).

324 Mandich, supra note 17, at 12.

325 See id. at 9-11. Of these, Antonio Marini, from Grenoble, probably owed his training to having grown up in one of the earliest centers of water-powered industrial technology in the West. See Marcel Silberstein, The Patents of Marini 1443-1457, 37 J. PAT. OfF. SoC'y 674, 674 (1955) (giving Marini's biography). Marini's hometown of Grenoble, hosted some of the first European fulling mills. Bloch, supra note 118, at 543. If we accept the thesis that the know-how for such mills was derived from the Levant and Islamic Spain, then the Grenoble installation was the result of a slow transfer of technology from newly re-conquered Spain. 
furnace for cloth dying, a printing press, and a water-raising device for use with mills. ${ }^{326}$

Finally in 1474, the Senate passed the general offer of a monopoly to anyone who could bring a new craft or device to Venice. Though the Venetian law used language that we associate with originality of creation, such as "genius" and "invention," in fact the Act aims only at encouraging the "discovery" and transfer from elsewhere ("from divers parts") of useful devices and the migration of those who through their "genius" know how to use them. ${ }^{327}$ The words "invention" and "genius" had not yet come to mean original invention; it was sufficient for Venice's purposes that the individual had acquired expertise in a novel technique. ${ }^{328}$ The Senate envisioned that the inventor or importer would train others in the know-how required to practice the art disclosed. ${ }^{329}$

The diffusion of intensive irrigation, dredging, and milling techniques throughout the neighboring Arab Islamic Empire provides a missing piece to the puzzle of patent law's origins. Venice's political economy may have been more favorable than that of other neighboring cities to the creation of bureaucratic rewards for invention. But increased appreciation of new hydraulic technology arose in Venice because so much technology was newly available. Engineering innovations from all over Eurasia traveled the main trade routes in the late Middle Ages and appeared in modified forms along the way. The techniques presented to the Venetian Senate in the 14th and 15th centuries represented both an ambitious Western culture of tinkering and improvement, and the inflow of a variety of tools simultaneously being exploited across the newly interconnected known world.

\section{LEgAL PRECURSORS TO THE 1474 ACT: THE USE OF INDUSTRIAL MONOPOLIES IN BYZANTIUM AND THE LEVANT}

The 1474 Act in Venice arose in response to transfer and assimilation of production techniques from the East. Not only the technology, but also the legal form itself was a novelty. Exclusive rewards for inventions were quite rare in Western Europe before $1415^{330}$ and did not exist in Roman antiquity. As

\footnotetext{
326 Mandich, supra note 17, at 13-17.

327 Mandich, supra note 2, at 181. The applicant might apply for a patent for a process used elsewhere in his own name even if he planned to import others to actually practice the work. Id.

328 KAUFER, supra note 40 , at 2; cf. Duffy, supra note 1, at 22-23 (noting that the early patent grants stressed the "sweat of the brow" of the inventor as proof of "inventiveness").

329 LONG, supra note 73, at 93.

330 See Prager, supra note 3, at 110; cf. Adam Mossoff, Rethinking the Development of Patents: An Intellectual History, 1550-1800, 52 Hastings L.J. 1255, 1259-60 (2001) (noting that the practice of awarding manufacturing monopolies did not begin until the 16 th century in England).
} 
with the technology, it is likely that inspiration for the notion of industrial monopolies as a method to encourage investment in new industries came from Venice's Eastern trading partners.

Of course, the basic premise underlying the award of proprietary rights to an invention has ancient roots. Societies have recognized property rights in the creation of new things, whether crops, livestock, or artwork, since before the Roman era. ${ }^{331}$ Rulers have granted economic privileges to those who provide useful services for just as long. It was not uncommon in ancient Rome, as well as in ancient China or Persia, for rulers to award monopolies over the sale or production of certain goods to court favorites or as rewards for military or other service. $^{332}$

Zeno's Edict temporarily suppressed the practice in the Roman West by criminalizing the exercise of monopoly rights over the sale of any useful articles or devices. ${ }^{333}$ The echo of this law was strongest felt in Western Europe, in which many territories continued to strike down commercial monopolies until the appearance of letters patent in Venice. ${ }^{334}$

In a sense, the Venetian Patent Act of 1474 represents a revival and adaptation of these ancient practices. The growing wealth and influence of the Italian city-states made state-created monopolies more attractive in the 15 th century than they would have been in the moribund agricultural territories of the European feudal era. Exposure to new arts and devices was a catalyst to revival of enthusiasm for economic monopolies. However the law also resembled contemporaneous practices in Venice's two dominant trading partners, Byzantine Constantinople and Mamluk Cairo.

\section{A. Tax Farming: A Long-known Monopoly}

Individual monopolies over industrial sectors, though unfamiliar to early medieval Europe, were available in the city-states of the Eastern Mediterranean where Zeno's law had had little lasting influence. In particular, the use of tax farming - that is, delegation of oversight and taxing authority over a segment of the economy to a private individual in return for a lump sum payment-was common. ${ }^{335}$ For the granting state, tax-farming privileges eased

\footnotetext{
331 Gaius, 2 Institutes of Roman Law 167 (E. A. Whittuck ed., Edward Poste trans., 4th ed. 1904); Prager supra note 3, at 108-10.

332 See Hudson, supra note 38, at 14-16, 23.

333 Prager, supra note 3, at 114.

334 Id. at 122.

335 S.D. Goiten, 1 A Mediterranean Society: The Jewish Communities of the ARAB World as Portrayed IN THE DoCumENTS OF THE CAIRo GENIZA 73, 269 (1967) (of medieval Egypt: "The whole administration and economy of the country were based on tax-farming."); 2 GoITEIN, id. at 354 (1971); ASHTOR, supra note 114, at 137 (stating that tax farming prevailed everywhere in the caliphate, in Iraq, Persia, Syria, and Egypt).
} 
administration of diffuse territories by delegating tax enforcement and collection to local authorities. However, from the tax farmer's perspective, the benefit received could take the form of industrial monopoly over a particular craft sector or technique. ${ }^{336}$ This practice, which would have been familiar to Venetian merchants from their time in the Levant, forms the closest institutional precursor to the early industrial monopolies created in Venice.

Tax farming existed in various forms in ancient Rome, China, and Persia, and its use continued throughout medieval Southeast Asia, Byzantium, and the Muslim Levant. ${ }^{337}$ In most cases, rulers employed the practice not to encourage innovation, but to ease the burdens of revenue collection. ${ }^{338}$ Under these systems, states outsourced the right to collect taxes to private parties in return for lump-sum payments. ${ }^{339}$ Holders of tax-farming privileges would then receive the right to collect taxes from the agriculture, industry or business of a designated area. ${ }^{340}$ Any amount that the holder collected above what he had paid for the right represented his profit. ${ }^{341}$ These tax-farming monopolies primarily facilitated state financing and, as far as we know, only tangentially encouraged innovation.

For example, the emperors of late Byzantium used tax farming primarily as a method to pay soldiers or reward favorites and those who had provided service to the crown. ${ }^{342}$ Tax farming allowed cash-strapped rulers to

See, e.g., 1 GoITEIN, supra note 335, at 73, 269-70; 2 GoITEIN, id. at 363 (1971) (describing the activities of tax farmers during the Abuyyid and Fatimid era in Egypt and Syria). A database of the Geniza documents studied by Goitien is available at http://etc.princeton.edu/ genizaproject/index.php?proj_id=3\&action=view_project (last visited Oct. 8, 2015).

3371 Goltien, supra note 335, at 269; 2 GolTIEN, id. at 358-63 (1971); William P. Alford, Don't Stop Thinking About ... Yesterday: Why There Was No Indigenous Counterpart to Intellectual Property Law in Imperial China, 7 J. Chinese L. 3, 9 (1993) (observing that imperial delegation of market control to local merchants and clan elders in China was "reminiscent of taxfarming"); Hudson, supra note 38, at 15, 25 (discussing tax farming in Rome and the ancient Near East); PoMERANZ, supra note 6, at 174-76 (describing tax farming in medieval China and India). See generally DARLING, supra note 38, at 120-28 (1996) (discussing the history of taxfarming practices).
}

338 E.g., DARLING, supra note 38, at 120-22 (discussing the historical advantages and purposes of tax farming); KeITH HoPkins, CONQUERORS AND SLAVES: SOCIOLOGICAL STUdIES IN ROMAN HISTORY 43-44 (1981) (asserting that tax farming offered a steady, low-risk form of revenue for Roman imperial administration).

339 DARLING, supra note 38, at 119-20.

3401 GoITIEN, supra note 335, at 73; 2 GoITEIN, id. at 363 (1971); see also MARK BARTUSIS, LAND AND PRIVILEGe IN Byzantium: The Institution of PRONOIA 130-31 (2012) (describing the sale of tax-farming privileges in Byzantium).

341 ASHTOR, supra note 114, at 193; BARTUSIS, supra note 340, at 413 (describing the pronoia holder's incentive to increase income from his estate over the amount he paid to the fisc in basic taxes); 1 GoITIEN, supra note 335, at 73; 2 GoITEIN, id. at 363 (1971).

See BARTUSIS, supra note 340 , at 116-18, 281, 288-89. 
administer their territories while preserving bullion for military campaigns. ${ }^{343}$ Most tax farming, or "pronoia" as it was known in Greek lands, related to taxes on land holdings and farming activity, but pronoia could also give holders the right to collect customs on trading or milling activity within their territory. ${ }^{344}$ Pronoia occasionally also referred to an outright grant to control either requisition or supply of a commodity on behalf of the Crown. ${ }^{345}$

During the era of the Crusades, tax farming of a more industrial kind flourished in the territories of medieval Egypt and Syria. The Fatimid and Abuyyid administrations of Egypt and Syria in the 10th through 12th centuries used a somewhat unusual method of tax farming that relied on regular auctions to distribute privileges to local merchants and manufacturers. ${ }^{346}$ Iqtas, or rights of control and taxes over agricultural holdings, were given as payment to military commanders. ${ }^{347}$ But, in urban or trading areas, tax rights seem often to have been divided according to specific industrial or agricultural sectors rather than strictly according to geography. ${ }^{348}$ Bidders gained these rights through open auctions held every three or four years. ${ }^{349}$ Before the Mamluk period of the 13th and 14th centuries, those who bid were typically middle-class merchants or industrialists. ${ }^{350}$

Ownership of an industrial tax monopoly effectively made the taxfarmer the "sahib al-suq," the master of the market. ${ }^{351}$ Control over a craft meant that the tax farmer could choose to practice the technique himself or simply to collect fees from others. ${ }^{352} \mathrm{He}$ could issue trade licenses and through this power had control over the number of practitioners and the methods they used. $^{353}$ Tax farmers could also call on authorities to exclude unlicensed

Id. at 116.

344 Id. at 124 (pronoia grant included right to collect property taxes as well as secondary taxes on activity in the granted territory); id. at 297 (describing different kinds of pronoia); id. at 493 (pronoia included shares in local mills).

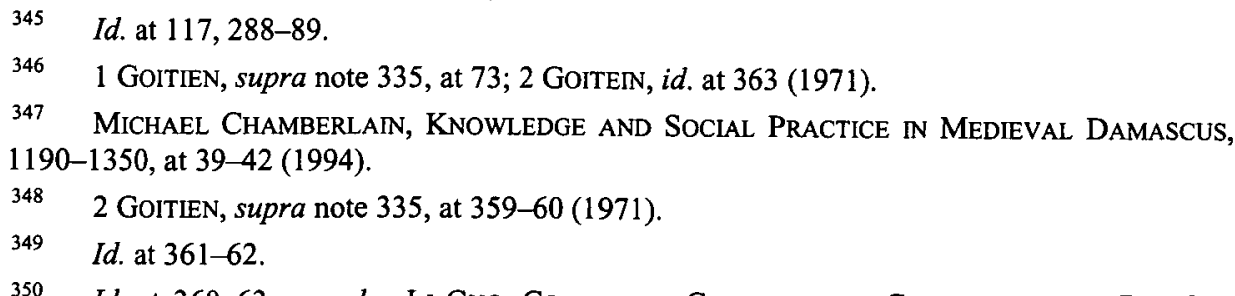

350 Id. at 360-63; see also Li Guo, COMMERCE, Culture, AND COMMUNITY IN A Red SEA PORT IN THE THIRTEENTH CENTURY: THE ARABIC DOCUMENTS FROM QUSEIR 97 (2004) (detailing how Red Sea merchant house also functioned as a tax farmer and market inspector for merchants in the area).

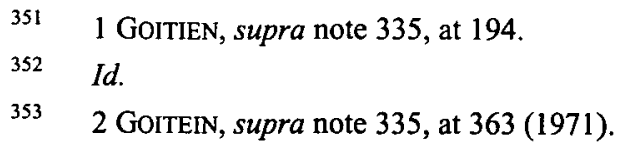


workshops. ${ }^{354}$ These industrial tax-farming privileges were purely intangible and so represent a distinct leap from other types of pre-patent monopoly schemes, such as mining claims or monastic tax schemes, associated with claims to real property.

Such rights provided incentives to innovate in the right hands. Industrialists seem to have used these market monopolies to protect investments in new equipment, techniques, and recruitment of skilled artisans. ${ }^{355}$ Those who bid the highest for tax farming offices were often experts in the trade who already possessed substantial knowledge and influence over the sector. ${ }^{356}$ These merchants had a low cost of collection of tariffs and were the most knowledgeable about the level of revenue the sector would produce. ${ }^{357}$ They had an incentive to increase returns and, therefore, were active in seeking out and introducing new techniques and recruiting foreign artisans. ${ }^{358}$

For example, monopolies on the sale and dying of silk are described in documents from 12th-century Cairo and a 12th-century traveler's description of Jerusalem under the Crusaders. ${ }^{359}$ Silk dying of the time required assimilating trade secrets from Persia, China, and India about how to produce certain colors. ${ }^{360}$ Presumably the holders of these monopolies, in both cases members of Jewish trading networks, played a role in transferring knowledge of these

\footnotetext{
354 Id. at 35, 67 (noting suits brought by holders of tax-farming privileges on silk-dying to exclude unlicensed competitors from the region).

355 Id.; see also ASHTOR, supra note 114, at 198 (describing the expansion of industry under the Fatimid administration in Egypt and Syria, including investments in new methods and recruitment of foreign artisans). Although Ashtor describes this period as one of "free enterprise," he earlier states that industry was managed through open bidding for tax farming privileges, $i d$. at 193 , and this is confirmed by other sources, e.g., 1 GoITIEN, supra note 335 , at 73; 2 GOITIEN, id. at 360, 363 (1971).

3562 GolTIEN, supra note 335, at 359-63 (1971) (noting, for example, that "[s]ince the Jews were so conspicuous in the silk industry, they were best qualified to take care of the taxes levied on it"); see also Guo, supra note 350 , at 120 .

3572 GolTIEN, supra note 335, at 363 (1971); see also Timur KurAn, THe Long DivergenCE: HOW ISLAMIC LAW HELD BACK THE MIDDLE EAST 134 (2011) (describing tax farming as a way for the state to get help collecting revenue from private parties knowledgeable about sectors that the state understood poorly).

358 See ASHTOR, supra note 114, at 198 (describing the expansion of industry under the Fatimid administration in Egypt and Syria, including investments in new methods and recruitment of foreign artisans); Ashtor, supra note 103, at pt. III, 266.

3592 GoITIEN, supra note 335, at 359-60, 361-62 (1971); BENJAMIN TUDELA, THE ITINERARY of BENJAMIN TUDELA 82 (Masa'ot shel Rabi Binyamin trans., 1983) (stating that Jerusalem "contains a dyeing-house, for which the Jews pay a small rent annually to the king, on the condition that besides the Jews no other dyers be allowed in Jerusalem").
}

360 See Jacoby, TRADE, COMMODITIES AND SHIPPING, supra note 259, at 548-49. 
secrets. ${ }^{361}$ The ability to control the local market and license practitioners provided some security against unlicensed appropriation of techniques. ${ }^{362}$

Tax farming on this peculiar Fatimid model migrated to Western Europe by at least the 12th century through the Norman kingdom of Sicily. After the Norman conquest of Sicily from the Egyptian Fatimid caliphate, Roger II, the new King, conserved and renewed pre-existing grants of privileges along the Fatimid Egyptian model. ${ }^{363}$ Roger consolidated fiscal control through the issuance of revocable royal charters, in contrast to the more common European feudal practice of delegating administration permanently to a loose confederation of hereditary vassals. ${ }^{364}$ His highest officers were Greeks and Arabs intricately acquainted with Fatimid and Byzantine practice, and his royal charters, written in Arabic, consciously imitated the titles and scripts of the Fatimid bureaucracy. ${ }^{365}$

Very few of these Sicilian grants have survived intact, and most define the privilege in terms of land estate boundaries or individual villeins, or taxpayers. ${ }^{366}$ Records of Norman practice, however, clarify that these privileges included the right to tax receipts from any industrial or commercial activity of the villeins or in the domain. ${ }^{367}$ Several of the grants included the right to collect revenues from specific markets, fisheries, or mills. ${ }^{368}$

Tax farming then offers an institutional precursor to the privilege system in medieval Venice. ${ }^{369}$ As Professor Thomas Nachbar has noted, for purposes of rent extraction, there is no difference between someone who holds a trade monopoly and someone who holds a delegation of regulatory authority over others engaged in the trade. ${ }^{370}$ In either case, the holder of the exclusive

Frumkin speculates that this was the purpose of the silk-dying monopoly noted by Tudela. See Frumkin, supra note 17, at 143.

362 See 2 GolTIEN, supra note 335, at 35, 67 (1971) (noting suits brought by holders of taxfarming privileges on silk-dying to exclude unlicensed competitors from the region).

363 See Jeremy Johns, ARabic Administration in Norman Sicily 195-96, 274 (David Morgan et al. eds., 2002).

364 See id. at 118; see also ALEX METCALFE, MusLims of MEdiEVAL ITALY 157 (2009) (noting "Roger's rights and privileges as king to dispose of his lands and men in the way in which he commanded via his officials").

365 See JoHNS, supra note 363 , at $274-77$; see also HIROSHI TAKAYAMA, THE ADMINISTRATION OF THE NORMAN KINGDOM OF SICILY 84 (1993).

366 See JoHNS, supra note 363, at 93-100, 144, 198-99.

$367 C f$. JoHNS, supra note 363 , at 144 (noting that listing individual villeins in a grant was simpler than listing all of their property and activities).

$368 I$ Id. at 92 (noting a grant including fishery, market, and anchorage taxes); id. at 110 (noting a grant to a personal foundation including oversight of two markets and revenue from an oven and a vineyard); $i d$. at 127, 295 (noting privileges granting tax rights to mills).

369 See Nachbar, supra note 42, at 1326; cf. 2 GoITIEN, supra note 335, at 361 (1971) (referring to the letter of appointment of a tax farmer as a "patent").

$370 \quad$ Nachbar, supra note 42, at 1326. 
right has a strong claim to the economic profits from the activity. ${ }^{371}$ The monopolist can charge monopoly prices to consumers, while the regulator can charge producers the difference between their cost and the monopoly price. ${ }^{372}$

Tax farming then could function as a poor man's patent. Like patent laws, commercial tax farming had the ability to delegate economic decisionmaking and its consequences to those with the best knowledge of the market. For the state, tax farming was cheaper to administer than Venetian-style patents. Authorities, consciously or unconsciously, could use the highest bid as a rough proxy for technical and managerial expertise. Tax farming therefore had the possibility of encouraging innovation if the privilege holder was entrepreneurial in spirit.

However, the practice could and did encourage corruption and stagnation in opportunistic hands. ${ }^{373}$ Tax-farmers prospered by increasing the amount they could collect from an industry; this could be done by increasing profits in the industry or by simply extracting a greater share of existing revenue and leaving producers poorer. In the later years of the Mamluk Empire in Egypt, when many monopolies were handed out as payments to military commanders, the latter was more often the model. ${ }^{374}$ The succeeding Ottoman administrations were also notoriously corrupt and inefficient in their use and abuse of tax monopolies. ${ }^{375}$

Tax farming privileges were also too tenuous to encourage sustained investment in technological improvements. In Cairo and Constantinople, tax farmers served at the pleasure of the military rulers. Their authority could be revoked in the event of a higher bidder ${ }^{376}$ or their wealth confiscated if it became too conspicuous. Historian Eliyahu Ashtor has detailed how confiscatory practices by the Mamluk sultans and amirs toward private industrialists stifled investment in technological innovation in the Levantine sugar, textile, and paper industries in the 15 th century. ${ }^{377}$

While abuses lowered the value of these monopolies in the Eastern Mediterranean, commercial tax farming began to flourish in Venice by the 14th century. Venice's preeminent economic historian, Frederic C. Lane, reports that beginning in 1315 authorities often auctioned off monopolies over particular

\footnotetext{
371 Id.

$372 \quad I d$. at 1377.

373 E.g., HOPKINS, supra note 338 , at 44 (discussing the drawbacks of tax farming in classical Rome).

3742 GolTIEN, supra note 335, at 261 (1971).

375 For a fuller discussion of Ottoman tax-farming practices, see DARLING, supra note 38 , at 119-87.

3762 GoITIEN, supra note 335 , at 361 (noting that after the Fatimid era, out-bidding incumbent tax farmers was a common practice).

377 Ashtor, supra note 103, at pt. III, 240-45, 266 (noting that "rich merchants no longer invested their capital in factories that could easily be confiscated").
} 
sea routes or trades to private partnerships or joint ventures. ${ }^{378}$ The partners agreed to pay the freight and expenses for the state-supplied galleys, and received all profits from the venture in return. ${ }^{379}$ Lane attributes the inspiration for such monopolies to "tradition inherited from Ptolemaic and Roman times and transmitted by Moslems and especially by the Byzantine Empire."380 Landbased tax farming was also prevalent in Venetian holdings in the former Byzantine Empire. In Cyprus, Greek industrialists lent money to the Venetian state in return for the rights to collect revenues from farms, mills, and cotton plantations. ${ }^{381}$

Franciscus Petri, the first on record to suggest the idea of a restrictive monopoly over a new industrial device came from Rhodes, an island that had been alternatively under Byzantine or Muslim rule for centuries. He was surely also familiar with the practice of tax farming in its agricultural and marketbased forms. ${ }^{382}$ His proposal-that he introduce a new type of mill in return for the rights to collect receipts from that and any similar mill for 50 years-is roughly analogous to the concept of rewarding service to the state with the right to revenues from a particular voyage, mill, or general technological sector. ${ }^{383}$

Many of initial holders of industrial privileges in Venice and other late medieval Italian cities were themselves merchants with extensive contacts in and exposure to the Eastern Mediterranean. ${ }^{384}$ Often these merchants petitioned the state for a monopoly over a new technique and then recruited artisans with the necessary expertise from a foreign locale. ${ }^{385}$ These merchants operated in a

378 LANE, supra note 162 , at 138-40 (noting that chartering a galley was very similar to tax farming); Frederic C. Lane, Venetian Merchant Galleys 1300-1334: Private and Communal Operation, 38 SpECulum 179, 179-80, 182-83, 191 (1963).

379 Lane, supra note 378 , at $182-83$.

$380 \quad$ Id. at 179.

381 See, e.g., Benjamin Arbel, Greek Magnates in Venetian Sicily: The Case of the Synglitico Family, 49 Dumbarton OAKS PAPERs 325, 325-37 (1995) (describing a Cypriot Greek family that rose from administrators in the state bureaucracy to powerful magnates through the purchase of tax-farming estates in the early 16 th century).

382 See Luttrell, supra note 323, at 768-70 (discussing Hospitaller grants of land and fiefs in Rhodes in return for service or to industrialists in exchange for annual payments); Mark C. Bartusis, Serbian Pronoia and Pronoia in Serbia: The Diffusion of an Institution, RECUEIL DES TRAVAUX DE L'INSTITUT D'ETUDES BYZANTINES XLVIII 177, 178 (describing Venetian adaptation and use of Byzantine pronoia in newly acquired territories).

$383 C f$. DARLING, supra note 38, at 126 (noting that common uses of tax farming under the Ottomans were revenues for industries and enterprises such as mills, mines and dye-houses).

384 Cf. MuHAMMAd IBN AHMAD (CALlED IBN JubaIR), THE Travels of IBN Jubayr, 301, 317 (R.J.C. Broadhurst trans., 1952) (translating diary of a 12th-century Spanish-Muslim pilgrim who noted that in Acre under the Franks, the collection of customs taxes had been farmed out to a local Christian in retum for a large payment).

385 See, e.g., MOLÀ, supra note 98, at 5-6 (describing proposals by nobles and entrepreneurs to recruit artisans to establish silk crafts in various Italian cities); Luca Mola, Inventors, Patents, 
manner very similar to the industrial tax farmers of the Eastern Mediterranean: they leveraged their knowledge of a trade into the procurement of a monopoly and then recruited workers with technical knowledge to improve the industry. ${ }^{386}$

Venice's innovation was to embed these rewards in a parliamentary system in which merchants played an active and durable part. ${ }^{387}$ Venetian elites were merchant families who by law controlled the Senate and access to powerful administrative offices. ${ }^{388}$ Not surprisingly, the privilege awarded in Venice took a more stable and predictable form than the autocratic system prevalent in the Eastern Mediterranean and elsewhere. This stability in turn was conducive to greater overall investment in technological progress.

Transference to Venice required an adjustment in form. The role served by the commercial tax-farmer in the Levantine East was served in Western Europe by guilds. ${ }^{389}$ Guild officers acted as representatives of the state, and collected necessary taxes from their members, who in turn held collectively the exclusive right to practice a craft. ${ }^{390}$ Through the guild structures, artisans in Western cities had political influence that craft syndicates east of the Mediterranean did not. ${ }^{391}$ As guilds already exercised tax monopolies over their sector, merchants looking to invest in new technologies required a different form of privilege that would not threaten the guild privileges. Entrepreneurs in Venice therefore needed a basis for exclusivity beyond tax administration and found it by showcasing the novelty and utility of their proposed operations.

Tax farming and patent prerogatives continued to be intertwined, however, even in the West. Once loosened from the shadow of Zeno's Edict, officials in Western Europe sold trade monopolies alongside patents for new inventions whenever they could get away with it. The practice was common in 15th-century Germany and in Elizabethan England. ${ }^{392}$ Merchants in Germany

and the Market for Innovations in Renaissance Italy, in 32 HISTORY OF TECHNOLOGY 7, 8 (Ian Inkster ed., 2014).

386 Cf. AsHTOR, supra note 114, at 198 (noting how industrialists in Fatimid Cairo, presumably operating under tax-farming monopolies, recruited foreign artisans to expand industry).

387 See Nard \& Morriss, supra note 8 , at 249; see also 1 GoITIEN, supra note 335 , at 70 (noting that "in Europe the merchant class gained political power,... [but] no such developments took place in the Muslim world").

388 See Nard \& Morriss, supra note 8, at 249; Lane, supra note 378, at 179.

389 See Nachbar, supra note 42, at 1320.

390 See MACKENNEY, supra note 187 , at 9.

391 E.g., ASHTOR, supra note 114, at 294 (noting the decline in political power of associations of craftsmen in the Near East in the late middle ages).

392 See, e.g., LAWRENCE Stone, THE Crisis OF THE ARISTOCRACY, 1558-1641, at 428-39 (1965) (describing numerous farms of customs, duties, and grants of trade monopolies in the Elizabethan and early Stuart eras). 
succeeded in banning the practice in $1512 .^{393}$ It took longer in England, but the effect was more lasting. ${ }^{394}$ One of the main purposes of the 1624 Statute of Monopolies in England, the statute long considered to be the first precursor to modern patent law, was to ban the issuance of trade monopolies in exchange for payment. ${ }^{395}$

\section{CONCLUSION}

In the last 20 years, patent law has become global. Developing economies across the globe must adopt an Anglo-European style patent regime as a condition of participation in multilateral trading systems such as the World Trade Organization. Negotiations over the WTO-TRIPs regime have been stalled for nearly a decade over competing demands for greater enforcement from the most developed countries, and more leeway for development and technology transfer from less-developed nations.

A more complete picture of the origins of patent law has several lessons for this patent and development debate. First, this history should cause us to revise contemporary thinking about the nature and purpose of patents. For most of its formal 800 year history, and for centuries of informal practice before that, patent law was primarily a tool of knowledge diffusion. It was not until well into the 19th century that the focus of patent law shifted from encouraging the training of local workers in imported arts to encouraging the written disclosure of original, "conceptual" innovation. ${ }^{396}$ Partially the cause of the shift was industrialization, which made worker skill a commodity. ${ }^{397}$ Laborers did not require long apprenticeships and training to master the routine movements of large machinery. ${ }^{398}$ Therefore the public benefit of patent law became instead the disclosure of the conceptual invention itself. ${ }^{399}$ Enterprises

393 See Frank D. Prager, Historic Background and Foundation of American Patent Law, 5 AM. J. LEGAL HIST. 309, 310 (1961).

$394 \quad I d$.

395 See B. Zorina Khan \& Kenneth L. Sokoloff, History Lessons: The Early Development of Intellectual Property Institutions in the United States, 15 J. ECON. PERSP. 233, 235 (2001).

396 See Duffy, supra note 51, at 1365; E. Wyndham Hulme, History of the Patent System Under the Prerogative and at Common Law: A Sequel, 16 L. Q. Rev. 44, 56 (1900) (noting that switching from a focus on the practice of an invention to the exposition of an invention, "relaid the foundations of [modern] patent law").

397 Cf. E. Wyndham Hulme, On the Consideration of the Patent Grant, Past and Present, 13 L. Q. REv. 313, 317 (1897) (distinguishing between pre- and post-industrial patent grants, where the former established entire new forms of manufacture, and the latter differentiated between new processes within established kinds of manufactures).

398 See Duffy, supra note 51, at 1370.

399 See id. at 1362. 
all over the globe are still fighting over what kinds of "conceptual" innovation produce sufficient benefit to qualify for patent rewards. ${ }^{400}$

It is worth asking whether this reconfiguration in the law is globally efficient; that is, does it allow the advantages of advanced technology to reach the most people in the most beneficial ways. In much of the developing world, the industrial era has taken hold only incompletely. Amidst industrial projects, large pockets of the more agrarian, artisanal economy still function. Even in industrialized nations, awards for cutting-edge innovation favor certain kinds of workers and skills but disadvantage others. ${ }^{401}$ Those with access to cutting-edge technology and education can compete in a worldwide race that rewards absolutely novel innovation. This race has little attraction for those locked out of the machine and information ages.

Furthermore, a focus on simple "disclosure" of an invention as sufficient collateral to underwrite a 20-year monopoly discounts the historical emphasis on the teaching and training of others. In both the developed and the developing world, the award of hold-up rights over technical practice to those who are not developing or practicing an invention in the jurisdiction has produced more costs than benefits. ${ }^{402}$ The old Venetian patent model, with its focus on the development of human capital, may perhaps be an equally salient model to the rigid system embodied in the multilateral TRIPS agreement.

Second, the notion that patent laws are a purely "Western" institutional creation does not stand up to scrutiny. Venice's Act of 1474 grew out of competition to assimilate technical knowledge from non-Western trading partners. It very likely adapted a regulatory form used throughout antiquity, and re-introduced through trade with the Byzantines and Muslims: the tax monopoly. From Venice, the patent legal form continued to change and develop as it migrated across Europe and to the United States. It remained intermittently intertwined with the sale of tax monopolies for several centuries after its introduction in Venice. A more accurate statement about the Western roots of patent law, then, is that the form represents a uniquely Western adaptation of an ancient and widespread method of industrial administration.

Finally, understanding patent law's development as a slow, crosscultural phenomenon casts new light on the formation of new legal institutions

\footnotetext{
400

See, e.g., Alice Corp. Pty. Ltd. v. CLS Bank Int'l, 134 S. Ct. 2347 (2014) (declaring certain kinds of methods ineligible for patent protection); Reichman \& Dreyfuss, supra note 34 , at 892-93 (arguing that existing patent laws are suited to older technological concepts and precepts and that greater experimentation to tailor laws to new circumstances would be more beneficial than greater harmonization).

401 Reichman \& Dreyfuss, supra note 34, at 99-101, 111-12.

402 See, e.g., Duffy, supra note 51, at 1362-64 (discussing the problem of patent trolls); Gustavo Ghidini, On the Impact of TRIPS on "Least Developed Countries": A Tale of Double Standards?, 1 QUEEN MARY J. OF INTELL. PROP., 73, 77 (2011) (arguing that developing countries do not see benefits from patent protection if all the awards go to foreign multinationals that do not "work" the patents locally).
} 
generally. While many scholars have compared and contrasted European medieval institutions with those of other regions, very few studies have looked for continuity and conversation. This research shows that medieval European institutions were not so different from their counterparts across the Mediterranean. The divergence between Middle Eastern tax farming and European patents for invention was not a sudden break in 15th-century Venice. The modern patent system evolved gradually in Europe, over centuries. Understanding patent law's roots in the developing world, and the factors that led Europe and the United States to use this tool differently, can reveal insights into how patent law is likely to adapt and develop as it moves into new legal contexts today. 